\title{
FLORA DA SERRA DO CIPÓ, MINAS GERAIS: VOCHYSIACEAE1
}

\author{
GUSTAVO HIROAKI SHIMIZU \& KIKYO YAMAMOTO
}

\begin{abstract}
Departamento de Biologia Vegetal, Instituto de Biologia, Universidade Estadual de Campinas, Caixa postal 6109, 13083-970 - Campinas, SP, Brasil. (e-mail: gustavoshimizu@gmail.com, kymt21@yahoo.com.br)
\end{abstract}

\begin{abstract}
Flora of the Serra do Cipó, Minas Gerais: Vochysiaceae). The study of the family Vochysiaceae is part of the project "Flora of Serra do Cipó, Minas Gerais, Brazil". The family is represented there by 22 species of the genera Callisthene, Qualea, Salvertia, and Vochysia, respectively with four, four, one and thirteen species. Key to the genera and species, descriptions, illustrations and comments on the geographic distribution, habitat, phenology and morphological variations are presented.
\end{abstract}

Key words: Callisthene, Qualea, Salvertia, Vochysia, floristics, campo rupestre, cerrado, Espinhaço Range.

Resumo - (Flora da Serra do Cipó, Minas Gerais: Vochysiaceae). O estudo da família Vochysiaceae é parte do projeto "Flora da Serra do Cipó, Minas Gerais, Brasil". Esta família está representada na área por 22 espécies dos gêneros Callisthene, Qualea, Salvertia e Vochysia, respectivamente com quatro, quatro, uma e treze espécies. São apresentadas chaves para gêneros e espécies, descrições, ilustrações e comentários sobre distribuição geográfica, hábitat, fenologia e variações morfológicas.

Palavras chave: Callisthene, Qualea, Salvertia, Vochysia, florística, campo rupestre, cerrado, Cadeia do Espinhaço.

\section{Vochysiaceae}

Árvores, arbustos ou subarbustos. Folhas simples, sésseis ou pecioladas, de filotaxia oposta ou verticilada. Estípulas presentes, às vezes reduzidas ou aparentemente ausentes, transformadas ou não em glândulas, associadas ou não a glândulas axilares. Flores em tirsos terminais ou subterminais, isolados ou em grupos formando sinflorescências, raramente em cincinos de uma a poucas flores nas axilas das folhas terminais. Flores diclamídeas, monoclinas, zigomorfas. Cálice 5-mero, prefloração quincuncial, curtamente gamossépalo na base, com um lobo calcarado ou bursiforme na base da quarta sépala, maior que os demais lobos calicinais e cobrindo total ou parcialmente o botão floral. Corola 1-3(-5)-mera, pétalas livres, pouco ou fortemente desiguais entre si, imbricadas. Androceu formado por um único estame fértil, antera de deiscência rimosa, filete pouco ou bastante desenvolvido, estaminódios presentes ou ausentes. Ovário súpero, 3-carpelar, 3-locular, placentação axilar, com 1 a 12 óvulos por lóculo, 1 estilete, 1 estigma pequeno terminal, subterminal ou lateral. Fruto cápsula loculicida. Sementes 1 a várias por lóculo, aladas, achatadas, circulares ou elípticas, testa cartácea; embrião reto.

Bibliografia básica: Barbosa (1999), França (1996, 2005), Kawasaki (1995, 2006), Lisboa (2000), Martins (1981), Martius (1826), Passos \& França (2003), Shimizu \& Yamamoto (2012), Stafleu (1948, 1952, 1953), Vianna (2002), Warming (1875), Yamamoto (2009).

1 Trabalho realizado segundo o planejamento apresentado por Giulietti et al. (1987). Parte da dissertação de mestrado do primeiro autor, defendida no Instituto de Biologia da Unicamp. 
1. Corola com 1 pétala; cápsula com deiscência basípeta.

2. No fruto deiscente, exocarpo corticoso que se quebra irregularmente, separando-se facilmente do endocarpo cartilaginoso das valvas

2 '. No fruto deiscente, valvas formadas pelo pericarpo lenhoso e íntegro 1. Callisthene

1'. Corola com 3 ou 5 pétalas; cápsula com deiscência simultânea (não basípeta) ao longo da linha de abertura no meio do lóculo.

3. Corola com 5 pétalas praticamente iguais, brancas; estame e pétalas persistentes na antese

3'. Corola com 3 pétalas, a central geralmente maior que as laterais, amarelas; estame e pétalas geralmente caducos na antese

3. Salvertia 4. Vochysia

\section{Callisthene Mart.}

Árvores ou arbustos com ramos de maior calibre portando outros de menor calibre, semelhantes a folhas compostas pinadas (râmulos filomórficos), decíduos, com renovação foliar anual simultânea à floração. Casca dos ramos e dos râmulos não descamante em placas. Gemas peruladas globosas. Catáfilos geralmente presentes na base dos râmulos e das inflorescências. Folhas opostas dísticas, geralmente com variação no tamanho e forma da lâmina ao longo do râmulo; lâmina foliar dos râmulos em flor geralmente mais estreita, menor e com textura mais delicada que nos râmulos em fruto; múcron, se presente nas folhas jovens, geralmente decíduo e ausente nas folhas mais velhas que acompanham os frutos; estípulas caducas, não conspicuamente glandulares. Flores isoladas, axilares; brácteas caducas, raramente persistentes; pétala 1, oposta ao lobo do cálice calcarado, branca ou amarelo-clara; estame fora do plano de simetria, persistente na antese; estaminódios ausentes; óvulos 2 por lóculo; estigma terminal. Cápsula de deiscência basípeta, com columela central engrossada, exocarpo corticoso que se quebra irregularmente e se separa facilmente do endocarpo cartilaginoso das valvas persistentes. Sementes 1-2 por lóculo, circularmente aladas.

Chave para as espécies

1. Lâmina foliar sempre maior que $2 \mathrm{~cm}$ compr. 2. C. major

1'. Lâmina foliar nunca maior que $1,5 \mathrm{~cm}$ compr.

2 . Râmulos com mais de 10 pares de folhas ausentes. 4. C. minor

2'. Râmulos com mais de 10 pares de folhas presentes

3. Ramos eretos, râmulos floríferos ferrugíneo-tomentosos, pétala 1-1,2 x 1-1,1 cm

3'. Ramos pendentes, râmulos floríferos glabros, pétala 5-6 x 5-6 mm

1. C. erythroclada

3. C. microphylla

1.1. Callisthene erythroclada Warm. in Mart. \& Eichler, Fl. bras. 13(2): 28. 1875.

Árvores, 2,5-5 m alt. Ramos delgados, eretos. Râmulos densamente ferrugíneo-tomentosos quando em flor, glabros quando em fruto, com 10-14 pares de folhas. Estípulas bastante reduzidas, caducas. Pecíolo ca. $1 \mathrm{~mm}$ compr., glabro ou pubescente; lâmina foliar de râmulos em flor 7-14 x 4-9 mm, oblongo-elíptica ou lanceolada, cartácea; lâmina foliar de râmulos em fruto 12-15 x 6-10 mm, oval-oblonga, lanceolada, coriácea; face adaxial pubescente em folhas jovens e glabra em folhas adultas, nervura primária impressa, secundárias promínulas; face abaxial pubescente a pilosa em folhas jovens, principalmente na região da nervura primária, glabra em folhas adultas, nervura primária proeminente, secundárias planas a promínulas; ápice agudo, arredondado ou emarginado, podendo ou não ser mucronado; base arredondada ou subcordada; margem plana, ciliada ou glabra. Pedicelos 2-3 mm compr.; brácteas caducas; botões florais 7-11 × 3-4 $\mathrm{mm}$, retos, ápice agudo; cálcar ca. 1,7 x 1,3 mm, reto, cônico; sépala calcarada 7-11 mm compr.; lobos do cálice não calcarados laterais $3 \times 1-2 \quad \mathrm{~mm}$, lanceolados, ápice longo-acuminado, lobos anteriores 4-6 $\times 2 \mathrm{~mm}$, ovais, ápice acuminado; pétala 1-1,2 ×1$1,1 \mathrm{~cm}$, obcordada, branca ou amarelo-clara; estame 6-8 mm compr.; antera 2-3 mm compr., glabra; filete 4$5 \mathrm{~mm}$ compr.; ovário 1,1-1,2 x 0,9-1,4 mm, globoso, glabro; estilete 6-7 mm compr.; estigma capitado, terminal. Cápsula $10 \times$ 6-7 mm, globosa. Sementes não vistas.

Material examinado: Jaboticatubas: Rodovia Belo Horizonte - Conceição do Mato Dentro, km 117, J. Semir s.n., 3.XI.1978, fl. (UEC 52323, VIC 6281). Santa Luzia: idem, km 127, Palácio, H.L. Mello Barreto 8324, 3.IX.1933, fr. (BHCB, GUA). Santana do Riacho: Estrada da Usina, CFSC 6777, col. I. Cordeiro et al., 10.XI.1980, fl./fr. (SP, SPF, UEC); Rodovia Belo Horizonte - Conceição do Mato Dentro, km 125, 
Flora da Serra do Cipó, Minas Gerais: Vochysiaceae

Córrego Três Pontinhas, CFSC 12902, col. J.R. Pirani et al., 7.III.1992, fl. (SPF, UEC).

Material adicional: Minas Gerais. Diamantina: Boa Vista - Extração, H.L. Mello Barreto 9677, 9.XI.1937, fl. (BHCB, SPF). Sem localidade: Vale do Rio Santo Antônio, A.P. Duarte 11936, 21.X.1969, fl. (GUA).

Callisthene erythroclada ocorre apenas em Minas Gerais, principalmente na região de Diamantina, em capões de mata. Os ramos eretos e o indumento ferrugíneo-tomentoso dos râmulos jovens diferenciamna de C. microphylla. Na Serra do Cipó foi coletada em flor nos meses de março e novembro e em fruto nos meses de setembro e novembro.

1.2. Callisthene major Mart., Nov. Gen. sp. pl. 1: 124, tab. 75. 1826.

Nome vulgar: itapicuri, tiriba, pau-terra-do-mato, jacaré-mirim.

Fig. $1 \mathrm{~A}-\mathrm{C}$

Árvores ou arvoretas, 1,5-15 m alt. Ramos delgados, eretos. Râmulos pubescentes a pilosos, gríseos quando jovens, glabros quando adultos, com 8-10 pares de folhas. Estípulas cônicas, ca. 0,5 mm compr., caducas. Pecíolo ca. $1 \mathrm{~mm}$ compr., glabro ou pubescente; lâmina foliar de râmulos em flor 2-3,3 $x$ 0,8-1,1 cm, oblongo-elíptica ou lanceolada, cartácea; lâmina foliar de râmulos em fruto $2-4 \times 0,8-1,6 \mathrm{~cm}$, oval-oblonga, elíptica, lanceolada ou oval, coriácea; face adaxial pubescente em folhas jovens e glabra em folhas adultas, nervura primária impressa, secundárias promínulas; face abaxial pubescente em folhas jovens, principalmente na região da nervura primária, e glabra em folhas adultas, nervura primária proeminente, secundárias planas a promínulas; ápice agudo, arredondado ou emarginado, podendo ou não ser mucronado; base arredondada ou subcordada; margem plana, ciliada ou glabra. Pedicelos 3-4 mm compr.; brácteas caducas; botões florais 12-13 x 4 $\mathrm{mm}$, retos, ápice agudo; cálcar 2,3-2,6 x 1,4 mm, reto, cilíndrico; sépala calcarada ca. $12 \mathrm{~mm}$ compr.; lobos do cálice não calcarados laterais $3-4 \times 2 \mathrm{~mm}$, lobos anteriores ca. $5 \times 2 \mathrm{~mm}$, ovais, ápice acuminado ou agudo; pétala $12-13 \times 12 \mathrm{~mm}$, obcordada, branca com manchas amarelas na face adaxial; estame 8-9 mm compr.; antera ca. $3 \mathrm{~mm}$ compr., glabra; filete 5-6 mm compr.; ovário ca. 1,5 x 1,3 mm, globoso, glabro; estilete ca. $7 \mathrm{~mm}$ compr.; estigma capitado, terminal. Cápsula 12-17 x 11-14 mm, globosa. Sementes 1-2 por lóculo, 8-10 x 5-7 mm.

Material examinado: Jaboticatubas: São José de Almeida, A.F. Silva et al. 145, 9.VI.2001, fr. (BHCB). Santana de Pirapama: São José da Cachoeira, trilha para a Cachoeira

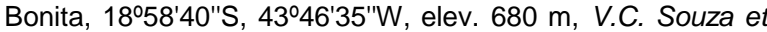
al. 32612, 18.II.2007, fr. (ESA, UEC). Santana do Riacho: área de camping ao norte da Pensão Chapéu de Sol, 1918'S, 4336'W, elev. $1050 \mathrm{~m}$, CFCR 15481, col. G.L. Esteves et al., 21.IX.1990, fl. (SPF); Córrego Três Pontinhas,
G.H. Shimizu et al. 115, 1.X.2008, fr. (UEC); estrada Cardeal Mota para Lapinha, Pico do Breu, 1906'44"S, 434'ㄷ'"W, K. Yamamoto \& L.S. Kinoshita 02/127, 24-27.IX.2002, fr. (UEC); Parque Nacional da Serra do Cipó, Canyon das Bandeirinhas, G.H. Shimizu et al. 219, 31.X.2008, fr. (UEC).

Callisthene major ocorre em matas de galeria ou capões de mata na BA, DF, GO, MG, MS, MT, PR e TO. Na Serra do Cipó foi coletada em flor em setembro e em fruto nos meses de fevereiro, junho, setembro e outubro.

Esta espécie possui duas variedades, C. major var. major e C. major var. pilosa Warm., que podem ser diferenciadas pelo indumento mais denso da segunda variedade, principalmente na face abaxial das folhas, pecíolos, pedicelos e casca dos râmulos jovens. Na Serra do Cipó há registro apenas da variedade típica.

Dentre as espécies de Callisthene que ocorrem na Serra do Cipó, C. major é a que apresenta folhas de maior comprimento, tanto nas plantas em flor como nas em fruto, atingindo 2 a $4 \mathrm{~cm}$ compr. Embora a largura das folhas varie de $8-16 \mathrm{~mm}$ nas plantas em fruto, esta medida nunca ultrapassa $1 \mathrm{~cm}$ nas demais espécies estudadas.

1.3. Callisthene microphylla Warm. in Mart. \& Eichler, Fl. bras. 13(2): 28, tab. 3, fig. 1. 1875.

Nome vulgar: vassourinha.

Fig. 1 D-E

Árvores ou arbustos, 1-4(-6) m alt. Ramos delgados, pendentes. Râmulos jovens e adultos glabros, com (7-)10-14(-19) pares de folhas. Estípulas lineares, ca. $0,2 \mathrm{~mm}$ compr., bastante reduzidas, caducas. Pecíolo ca. $1 \mathrm{~mm}$ compr., glabrescente; lâmina foliar de râmulos em flor 7-9 x 3-4 mm, rombóide ou lanceolada, cartácea a coriácea; lâmina foliar de râmulos em fruto 7-9(-14) x 3-4(-9) mm, rombóide ou lanceolada, cartácea a coriácea; face adaxial glabra, nervura primária levemente impressa, secundárias inconspícuas a promínulas; face abaxial glabra, nervura primária proeminente, secundárias planas; ápice agudo, arredondado ou emarginado; base arredondada a raramente cordada; margem plana, glabra. Pedicelos 2-4 mm compr.; brácteas persistentes; botões florais 5-6 x $2 \mathrm{~mm}$, retos, ápice agudo; cálcar 1,7-2 × $1 \mathrm{~mm}$, reto, cônico; sépala calcarada 5-6 mm compr.; lobos do cálice não calcarados laterais $1 \times 0,8 \mathrm{~mm}$, lobos anteriores 2,5-3 x 0,8-1,1 mm, ovais, ápice acuminado; pétala 5-6 x 5-6 $\mathrm{mm}$, obcordada, branca com manchas amarelas na face adaxial; estame 4-5 mm compr.; antera 1,5-2 mm compr., glabra; filete 2,5-3 mm compr.; ovário 0,7-1,3 x 1,1-1,3 mm, globoso, glabro; estilete 2-3 mm compr.; estigma capitado, terminal. Cápsula 1-1,2 x 0,9-1 cm, globosa a elipsóide. Sementes 1-2 por lóculo, 6-7 x 4$5 \mathrm{~mm}$. 


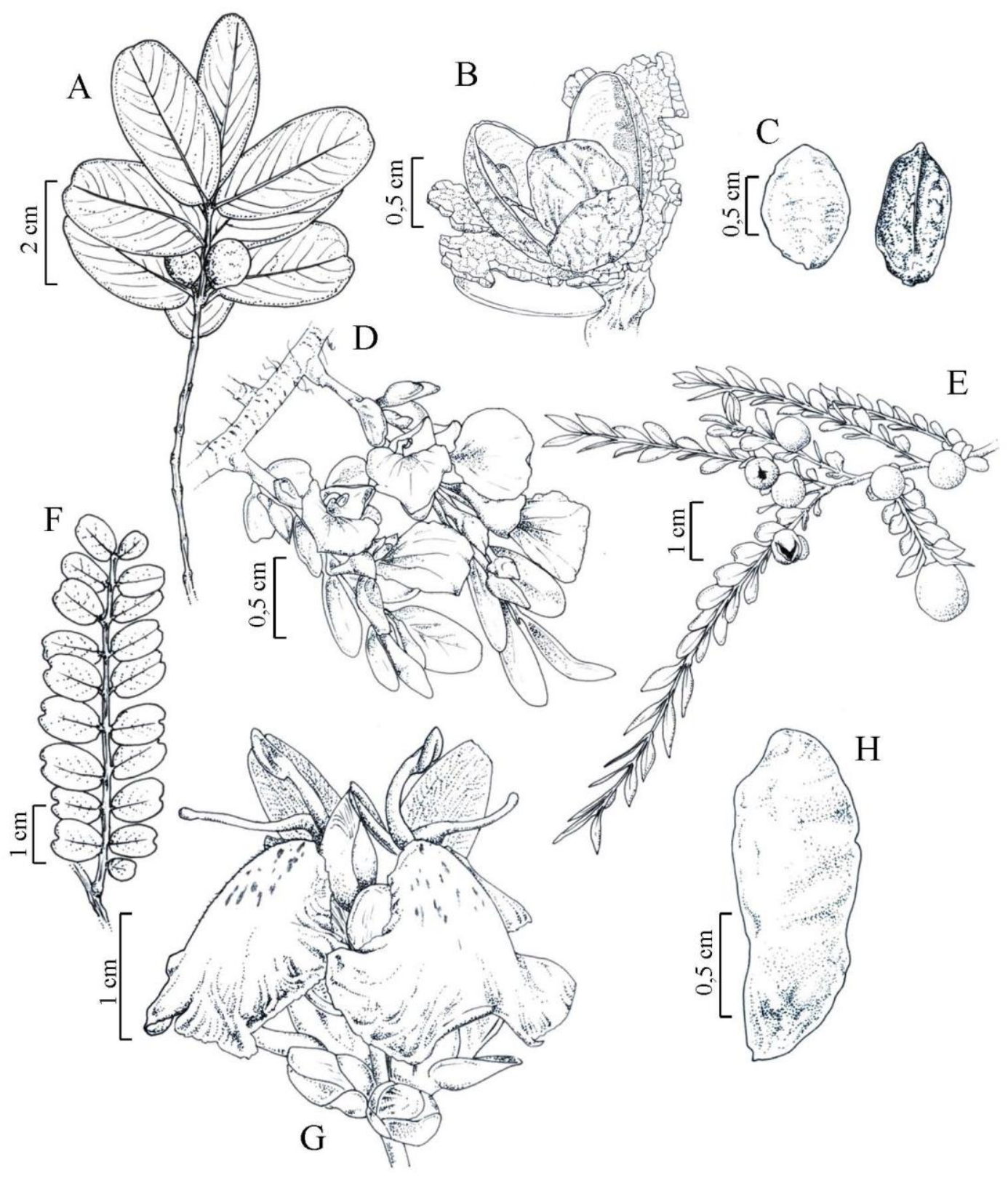

Fig. 1. A-C. Callisthene major Mart. A. Ramo com frutos imaturos; B. Fruto; C. Semente em vista abaxial à esquerda e adaxial à direita. D-E. Callisthene microphylla Warm. D. Ramo florífero; E. Ramo frutífero. F. Callisthene minor Mart., ramo. G-H. Qualea cordata Spreng. G. Porção da inflorescência; H. Semente. 
Flora da Serra do Cipó, Minas Gerais: Vochysiaceae

Material examinado: Santana de Pirapama: Fazenda Inhame, Serra Mineira, 185'S, 4354'W, CFSC 8212, col. I. Cordeiro et al., 24.III.1982, fr. (SPF, UEC); Fazenda Toucan Cipó, estrada para a captação, 1900'18"S, 4346'06"W, D.C. Zappi et al. 746, 16.Il.2007, fr. (ESA, SPF, UEC). Santana do Riacho: Lapinha, 1906'54"S, 4340'17"W, G.H. Shimizu et al. 183, 3.X.2008, fl. (UEC); idem, 1906'54"S, 4340'17"W, G.H. Shimizu et al. 184, 3.X.2008, fr. (UEC); Parque Nacional da Serra do Cipó, Serra da Bandeirinha, CFSC 10591, col. R. Simão et al., 10.IX.1987, fr. (SP, SPF); próximo à Fazenda Boa Vista, CFSC 7810, col. G.P. Lewis et al., 17.Il.1982, fr. (SPF, UEC); trilha dos Escravos, 1918'51"S, 43ำ36'26"W elev. 887 m, G.H. Shimizu et al. 54, 22.VII.2008, fr. (UEC) idem, 1918'54"S, 4336'22"W, elev. 879 m, G.H. Shimizu et al. 91, 25.VII.2008, fr. (UEC); idem, 1920'39"S, 43ํ3'38"W, G.H. Shimizu et al. 198, 4.X.2008, fl. (UEC); idem, 1920'39"S, 4335'38"W, G.H. Shimizu et al. 200, 4.X.2008, fr. (UEC).

Material adicional: Bahia. Entre Barreiras e Catete, à margem da BR-40, Brasília - Fortaleza, A.P. Duarte 9537, 28.X.1965, fr. (BHCB). Estrada Bahia - Fortaleza, no planalto da Serra das Divisões, A.P. Duarte 9509, 25.X.1965, fl./fr. (BHCB). Minas Gerais. Januária: Vale do Peruaçu, A. Salino \& L.C.N. Melo 3705, 26.X.1997, fl. (BHCB, SP). Manga: M.B. Horta et al. s.n., 26.Il.1991, fr. (BHCB 22188). São Gonçalo do Rio Preto: Parque Estadual do Rio Preto, $18^{\circ} 05^{\prime} \mathrm{S}$, 4320'W, J.A. Lombardi 3366, 17.XI.1999, fl. (BHCB); idem, da casa de hóspedes à cascata do Ribeirão das Eguas e então por fim ao camping, 180' $43^{\prime \prime} \mathrm{S}, 43^{\circ}=22^{\prime} 10^{\prime \prime} \mathrm{W}, J . A$. Lombardi et al. 3799, 8.IV.2000, fr. (BHCB).

Callisthene microphylla ocorre principalmente em campos e carrascos na região da Caatinga, mas também em campos rupestres de outras localidades (Stafleu 1952). É registrada nos estados da BA, CE, GO, MG, PA, PI e TO. Stafleu (1952) observou que esta espécie diferencia-se de todas as demais do gênero pelas folhas e flores bem diminutas e pelo número relativamente grande de pares de folhas por râmulo.

Foi coletada em campo rupestre, em flor no mês de outubro e em fruto nos meses de fevereiro, março, julho, setembro e outubro. Os ramos pendentes e botões florais pequenos (máximo de 6 $\mathrm{mm}$ compr.) distinguem $C$. microphylla das demais espécies do gênero que ocorrem na área de estudo.

1.4. Callisthene minor Mart., Nov. Gen. sp. pl. 1: 126, tab. 76. 1826.

Nome vulgar: pau-de-pilão.

Fig. $1 \mathrm{~F}$

Árvores ou arvoretas, 2-7 m alt. Ramos delgados, eretos. Râmulos castâneo-pubescentes quando jovens, glabros quando adultos, com 7-10 pares de folhas, nunca mais de 10. Estípulas inconspícuas, caducas. Pecíolo ca.1 mm compr., glabro; lâmina foliar de râmulos em fruto 9-15 x 6-9 mm, oblonga, oval-oblonga ou elíptica, coriácea; face adaxial glabra, apenas com indumento ao longo da nervura primária, nervura primária impressa, secundárias promínulas; face abaxial glabra, nervura primária proeminente, secundárias planas a promínulas; ápice agudo, arredondado ou mais frequentemente emarginado; base arredondada ou subcordada; margem plana, ciliada ou glabra. Flores não vistas. Cápsula 9-10 × 6-8 mm, globosa. Sementes 1-2 por lóculo, 5-6 x 3-4 mm.

Material examinado: Santana do Riacho: Rodovia Belo Horizonte - Conceição do Mato Dentro, km 116, mata ciliar do córrego Indequicé, CFSC 7239, col. A. Furlan et al., 19.IV.1981, fr. (SPF, UEC).

Material adicional: Bahia. Estrada Mucugê - Andaraí, CFCR 7105, col. G.P. Lewis et al., 17.XII.1984, fr. (SPF, RB). Distrito Federal: APA de Cafuringa, Fazenda Palestina, 1531'S, 4810'W, elev. $790 \mathrm{~m}$, V.V. Mecenas \& J.A. de Carvalho 14, 15.IX.1991, fr. (RB).

Callisthene minor ocorre na BA, DF, GO e MG, em áreas de capão e na borda de matas de galeria. Há registro para a Serra dos Carajás, no Pará (Silva et al. 1996), mas ainda é necessário analisar o material para confirmar identificação. Na área de estudo foi coletada em fruto no mês de abril.

A delimitação de C. minor ainda é muito problemática, havendo divergências nas monografias posteriores à revisão de Warming (1875). Difere de $C$. erythroclada e C. microphylla por nunca apresentar mais de 10 folhas por râmulo, e de C. major pelas folhas nunca maiores que $1,5 \mathrm{~cm}$ compr.

\section{Qualea Aubl.}

Árvores ou arbustos, sem râmulos filomórficos. Casca dos ramos e dos râmulos descamante em placas ou não. Gemas peruladas; catáfilos presentes. Folhas opostas, raramente em verticilos 3-meros; estípulas glandulares persistentes, às vezes inconspícuas, associadas a glândulas axilares crateriformes. Tirsos terminais ou terminais e axilares, com inflorescências parciais de cincinos opostos ao longo do eixo primário; brácteas caducas. Cálice com o maior lobo calcarado ou bursiforme; pétala 1, oposta ao lobo maior do cálice, branca, amarela ou violácea; estame fora do plano de simetria, persistente na antese; estaminódios ausentes; óvulos vários por lóculo; estigma subcapitado, terminal. Cápsula de deiscência basípeta, sem columela central engrossada, exocarpo unido ao endocarpo e formando pericarpo íntegro e lenhoso quando maduro. Sementes 2 a 12 por lóculo, unilateralmente aladas. 
1. Face adaxial da pétala densamente serícea; cálice com protuberância basal bursiforme 1. Q. cordata

1'. Face adaxial da pétala glabra ou esparsamente pilosa apenas na porção basal; cálice com cálcar clavado, subclavado ou cilíndrico.

2. Ramos com casca descamante em placas; cálcar com pelo menos $2 \mathrm{~cm}$ compr.; frutos sempre com mais de $4 \mathrm{~cm}$ compr 2. Q. grandiflora

2'. Ramos com casca não descamante em placas; cálcar menor que $1 \mathrm{~cm}$ compr.; frutos com até $4 \mathrm{~cm}$ compr.

3. Pétala violácea; frutos com superfície descamante

4. Q. parviflora 3 '. Pétala branca ou amarela; frutos com superfície não descamante

3. Q. multiflora

2.1. Qualea cordata Spreng., Syst. veg. (ed. 16) 1: 17. 1824.

Nome vulgar: dedaleira-preta, pau-terra.

Fig. $1 \mathrm{G}-\mathrm{H}$

Árvores ou arbustos, 1,7-5 m alt. Ramos tortuosos, casca não descamante em placas. Gemas peruladas globosas; estípulas subcrateriformes a cônicas, ca. $0,5 \mathrm{~mm}$ compr., às vezes inconspícuas. Folhas opostas; pecíolo 3-5(-6) mm compr., glabro a pubescente; lâmina foliar 4-7,5(-10) x 2-4,5(-6) cm, oval, oval-lanceolada ou oval-oblonga, coriácea; face adaxial glabra, às vezes glaucescente, nervura primária impressa a plana, secundárias promínulas; face abaxial glabra a pubescente, nervuras primária e secundárias proeminentes; ápice agudo, agudoacuminado ou obtuso, raramente arredondado ou emarginado; base cordada, raro arredondada ou truncada; margem plana. Inflorescências terminais, 7$13 \mathrm{~cm}$ compr., glabras a pubescentes; cincinos sésseis, 1-3-floros, opostos ao longo do tirso, distalmente com menos flores; pedicelos 2-3 mm compr.; brácteas caducas; botões florais $6-10 \times 4 \mathrm{~mm}$, retos, ápice obtuso; lobo do cálice bursiforme 12-13 $\mathrm{mm}$; lobos do cálice não bursiformes $5-8 \mathrm{~mm}$ compr., ovais, ápice obtuso; pétala 1,3-2 × $2 \mathrm{~cm}$, obcordada, branca com manchas vináceas, tornando-se amarelada após a fase fértil, densamente serícea na face adaxial, pubescente na abaxial; estame 11-14 $\mathrm{mm}$ compr.; antera 3-5 mm compr., glabra; filete 8-9 $\mathrm{mm}$ compr.; ovário 3-5 × $3 \mathrm{~mm}$, globoso, tomentoso; estilete 7-10 mm compr., cilíndrico, com tricomas apenas na porção basal. Cápsula $2-3 \mathrm{~cm}$ compr., elipsóide, ápice apiculado, base arredondada, superfície verruculosa, não descamante, glabra. Sementes 1-4 por lóculo, 13-19 x $5 \mathrm{~mm}$.

Material examinado: Jaboticatubas: estrada do IBAMA para Jaboticatubas, 1920'54"S, 4338'12"W, G.H. Shimizu et al. 120, 2.X.2008, fl./fr. (UEC); km 113, ao longo da rodovia Lagoa Santa - Conceição do Mato Dentro Diamantina, A.B. Joly et al. 4519, 18.X.1973, fl. (RB, SPF); km 114, CFSC 302, col. A.B. Joly et al., 7.VI.1970, fl. (SP);

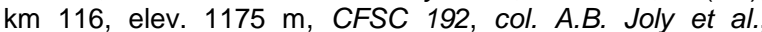
6.VI.1970, fl./fr. (SP). Santa Luzia: km 119, A.P. Duarte 6428, 25.X.1961, fl. (GUA, RB); km 127, Alto Palácio, A. Sampaio 6843, 2.Il.1934, fr. (GUA). Santana de Pirapama: Fazenda Toucan Cipó, estrada para a captação, 1900'18"S,
4346'6"W, elev. 720 m, D.C. Zappi et al. 757, 16.Il.2007, fr. (ESA, SPF). Santana do Riacho: elev. 1300 m, G. Martinelli 251, 10.V.1974, fr. (RB); afloramento entre Fazenda Palácio e estátua do Juca, K. Yamamoto \& A.R. Barbosa 00/10, 22.XI.2000, fl./fr. (UEC); Cardeal Mota, estrada em frente à Pousada Fazenda Monjolos, trilha do Paredão, próximo à cachoeira, L.S. Kinoshita et al. 36, 24.IX.2002, fl. (UEC); estrada da Usina, M.G.L. Wanderley et al. 586, 21.III.1983, bt./fr. (SP); idem, em direção à Serra Morena, 1916'02,0"S, 4336'11,6"W, elev. $1013 \mathrm{~m}$, G.H. Shimizu et al. 80, 24.VII.2008, fr. (UEC); idem, próximo à casa do Sr. José, S.M.C. Guerreiro et al. 1, 18.IX.2000, fr. (UEC); estrada de Cardeal Mota para Santana do Riacho, 1914'55"S, 4342'32"W, G.H. Shimizu et al. 166, 3.X.2008, fl./fr. (UEC); estrada Lagoa Santa - Conceição do Mato Dentro, D.S.D. Araújo 7719, 3.II.1987, fr. (GUA); estrada para Morro do Breu, 1906'44"S, 4341'53"W, K. Yamamoto et al. 181, 27.IX.2002, fl. (UEC); Fazenda Alto Palácio, 1917'S, 4334'W, elev. 1140 m, F.C.F. Silva 84, 23.IX.1981, fl. (GUA); Hotel Monjolos, em frente à sede, A. Salatino et al. 50, 25.IX.1995, fl./fr. (SPF, UEC); Rodovia Belo Horizonte Conceição do Mato Dentro, km 104, CFSC 11800, col. A. Freire-Fierro \& F.R.S. Pires, 23.XI.1990, fl./fr. (SPF); idem, km 105, CFSC 7443, col. J.R. Pirani et al., 4.X.1981, fl. (SPF, UEC); idem, curva da gameleira, CFSC 13889, col. A.A. Grillo et al., 5.IV.1995, fr. (SPF, UEC); idem, km 107, caminho para Usina Dr. Pacífico Mascarenhas, CFSC 9005, col. E. Forero et al., 7.IX.1980, fl./fr. (SP); idem, km 118, CFSC 7353, col. A.M. Giulietti et al., 30.VI.1981, fl. (SPF, UEC); idem, km 119, mata em frente à entrada da Fazenda Palácio, CFSC 9048, col. M.L. Kawasaki \& G.L. Esteves, 16.X.1982, fl./fr. (BHCB, SPF, UEC); idem, km 124, margem de riacho, elev. $1300 \mathrm{~m}$, H.C. Lima 412, 25.I.1978, fr. (RB); Lapinha, Pico do Breu, 1910'S, 4342'W, elev. 1126 m, A.M.G.A. Tozzi \& L.S. Kinoshita 562, 23.XI.2000, fr. (UEC); subida da Serra do Cipó, ao lado da Rodovia Lagoa Santa - Conceição do Mato Dentro, R. Mello-Silva et al. 1023, 8.IV.1995, fr. (SP, SPF); Usina de Força, $200 \mathrm{~m}$ do portão de entrada, $A$. Salatino et al. 61, 25.IX.1995, fr. (SPF).

Ocorre amplamente na Cadeia do Espinhaço, tanto na Bahia quanto em Minas Gerais, assim como em outras áreas de Minas Gerais (Serra da Canastra, Uberlândia), Distrito Federal, Goiás, Mato Grosso, São Paulo, Paraná, Paraguai e nordeste da Argentina. Foi coletada em cerrados e campos rupestres na Serra do Cipó, com floração nos meses de junho e de agosto a novembro e frutificação em quase todos os meses do ano, excetuando-se agosto e dezembro.

Qualea cordata Spreng. foi efetivamente publicada em 1824, apesar de constar 1825 na capa 
Flora da Serra do Cipó, Minas Gerais: Vochysiaceae

da obra de Sprengel (Stafleu \& Cowan 1985). Amphilochia cordata Mart., erroneamente tratada como basiônimo de $Q$. cordata, foi efetivamente publicada em 1826, e não em 1824, como consta na página de rosto da obra de Martius (Stafleu \& Cowan 1981).

$\mathrm{Na}$ área de estudo, Qualea cordata difere das outras espécies do gênero por apresentar pétala serícea na face adaxial e protuberância bursiforme na quarta sépala, em vez de cálcar desenvolvido.

2.2. Qualea grandiflora Mart., Nov. Gen. sp. pl. 1: 133, tab. 79. 1826.

Nome vulgar: pau-terra, pau-terra-da-folha-larga.

Fig. 2 A-D

Árvores, 2,5-6 m alt. Ramos tortuosos, casca descamante em placas. Gemas peruladas ovóides; estípulas cônicas, 0,5-1 $\mathrm{mm}$ compr., às vezes inconspícuas. Folhas opostas; pecíolo 6-10 mm compr., pubescente a piloso; lâmina foliar 8-18 x 4,5-8 $\mathrm{cm}$, oblonga ou sub-oblonga, cartácea a coriácea; face adaxial glabra, glabrescente na nervura primária, nervuras primária e secundárias impressas; face abaxial tomentulosa, nervuras primária e secundárias proeminentes; ápice brevemente acuminado; base arredondada, subcordada ou obtusa; margem plana. Inflorescências terminais, $5-15 \mathrm{~cm}$ compr., pilosas; cincinos 1-4-floros, opostos ao longo do tirso, distalmente com menos flores, pedúnculos ca. $5 \mathrm{~mm}$ compr.; pedicelos 1-2,5 cm compr.; brácteas caducas; botões florais ca. $2 \times 1 \mathrm{~cm}$, retos, ápice agudo; cálcar 1,5-2,5 x 0,2 cm, incurvo, cilíndrico; sépala calcarada 1,8-2,8 cm compr.; lobos do cálice não calcarados ca. $1,5 \mathrm{~cm}$ compr., ovais, ápice obtuso; pétala 2,1-4 x 3,5$6 \mathrm{~cm}$, obcordada, amarela, glabra; estame ca. $14 \mathrm{~mm}$ compr.; antera ca. $8 \mathrm{~mm}$ compr., glabra; filete ca. 6 mm compr.; ovário ca. $4 \times 4 \mathrm{~mm}$, globoso, tomentoso; estilete ca. $16 \mathrm{~mm}$ compr., cilíndrico, glabro. Cápsula 6-11 cm compr., oblonga, ápice apiculado, base arredondada, superfície verruculosa, não descamante, glabra. Sementes numerosas, $42-45$ x 12-15 mm.

Material examinado: Jaboticatubas: cerrado próximo à Gruta do Gentio, J. Semir \& M. Sazima s.n., 15.XII.1974, fl. (UEC 15779); trilha de baixo, próxima à sede do IBAMA, que segue para o Poço Azul, 1921'24,1"S, 4337'11,3"W, G.H. Shimizu \& J.G. Rando 7, 9.I.2008, fl. (UEC). Santana do Riacho: Alto do Curral Queimado, K. Yamamoto \& A.R Barbosa 00/17, 23.XI.2000, fr. (UEC); Cardeal Mota, APA Morro da Pedreira, trilha para o Morro da Pedreira, base do morro, à beira da estrada para Melo e Santana do Riacho, 1918'21"S, 4336'58"W, elev. 880 m, J.R. Pirani et al. 5568, 17.I.2007, fl. (RB, SPF, UEC); estrada de Cardeal Mota para Santana do Riacho, 1919'17"S, 4337'56"W, G.H. Shimizu et al. 142, 3.X.2008, fr. (UEC); estrada de terra Cardeal Mota São José da Serra, cerrado logo após igreja, CFSC 13946 , col. M. Sztutman et al., 6.IV.1995, fr. (SPF); estrada do distrito de Cardeal Mota a Santana do Riacho, 1916'21,0"S, 4340'37,1"W, elev. $872 \mathrm{~m}$, G.H. Shimizu et al. 98, 25.VII.2008, fr. (UEC); Usina Coronel Américo Teixeira, P.M. Andrade \& M.A. Lopes s.n., 15.IV.1985, fl./fr. (UEC 62861).
Qualea grandiflora ocorre em praticamente todas as formações de cerrado da América do Sul e nas campinas amazônicas. É registrada nos estados do AC, AM, BA, CE, DF, GO, MA, MG, MS, MT, PA, PI, PR, RO, SP e TO, Paraguai, Bolívia, Peru e Suriname. $\mathrm{Na}$ área de estudo foi coletada em flor nos meses de janeiro, abril e dezembro, e em fruto nos meses de abril, julho, outubro e novembro. É facilmente identificável pela casca descamante em placas nos ramos e pelas flores e frutos de dimensões bem maiores do que nas outras espécies locais de Qualea.

2.3. Qualea multiflora Mart., Nov. Gen. sp. pl. 1: 134, tab. 80. 1826.

Nome vulgar: pau-terra, pau-terra-do-campo.

Fig. 2 E

Árvores ou arbustos, 1,2-8 m alt. Ramos tortuosos, casca não descamante em placas. Gemas peruladas ovóides; estípulas subcônicas, 0,5-1 mm compr., às vezes inconspícuas. Folhas opostas ou em verticilos 3-meros; pecíolo 3-6 $\mathrm{mm}$ compr., glabro a piloso; lâmina foliar 4-14,5 x 2,5-5 cm, oblonga, lanceolada, oval ou elíptica, cartácea; face adaxial glabra a pubescente, nervura primária impressa, secundárias levemente impressas; face abaxial glabra a pilosa, nervuras primária e secundárias proeminentes; ápice curto-acuminado, às vezes obtuso ou agudo; base obtusa ou arredondada, às vezes subcordada; margem plana. Inflorescências terminais, 9,5-19(-27) cm compr., pilosas; cincinos 1-5floros, opostos ao longo do tirso, distalmente com menos flores, pedúnculos 1-3 mm, às vezes ausentes, conferindo aspecto fasciculado aos cincinos; pedicelos 5-12 mm compr.; brácteas caducas; botões florais 811 × 4-5 mm, retos, ápice agudo; cálcar 6-8 x 2 mm, reto ou recurvo, cilíndrico ou clavado; sépala calcarada 8-10 mm compr.; lobos do cálice não calcarados 5-7 mm compr., ovais, ápice obtuso; pétala $2-2,5 \times 2,2-3,2 \mathrm{~cm}$, obcordada, branca com linhas amarelas e manchas róseas na região central da face adaxial, após a polinização amarelo claro ou creme, com linhas amarelas e manchas arroxeadas na região central da face adaxial, glabra; estame ca. $14 \mathrm{~mm}$ compr.; antera ca. $4 \mathrm{~mm}$ compr., glabra; filete ca. $1 \mathrm{~cm}$ compr.; ovário 3 × 2-3 mm, globoso, tomentoso; estilete ca. $8 \mathrm{~mm}$ compr., cilíndrico, com tricomas apenas na porção basal. Cápsula 3-4 cm compr., elipsóide a ovóide, ápice apiculado, base arredondada, superfície verruculosa, não descamante, glabra. Sementes 2 por lóculo, ca. $3 \times 1 \mathrm{~cm}$.

Material examinado: Jaboticatubas: estrada para a sede do IBAMA, CFSC 12806, col. J.R. Pirani et al., 6.XII.1991, fl. (SPF); estrada que liga MG-010 à Sede do IBAMA, G.H. Shimizu \& J.G. Rando 3, 8.I.2008, fl. (UEC); margem oposta da antiga foz do córrego Engenho, 1920'36,4"S, 4336'29,6"W, G.H. Shimizu \& J.G. Rando 18, 11.I.2008, fl. (UEC); proximidades da sede do IBAMA, 1920'S, 434' W, elev. 600-700 m, L.S. Kinoshita \& M.E. 


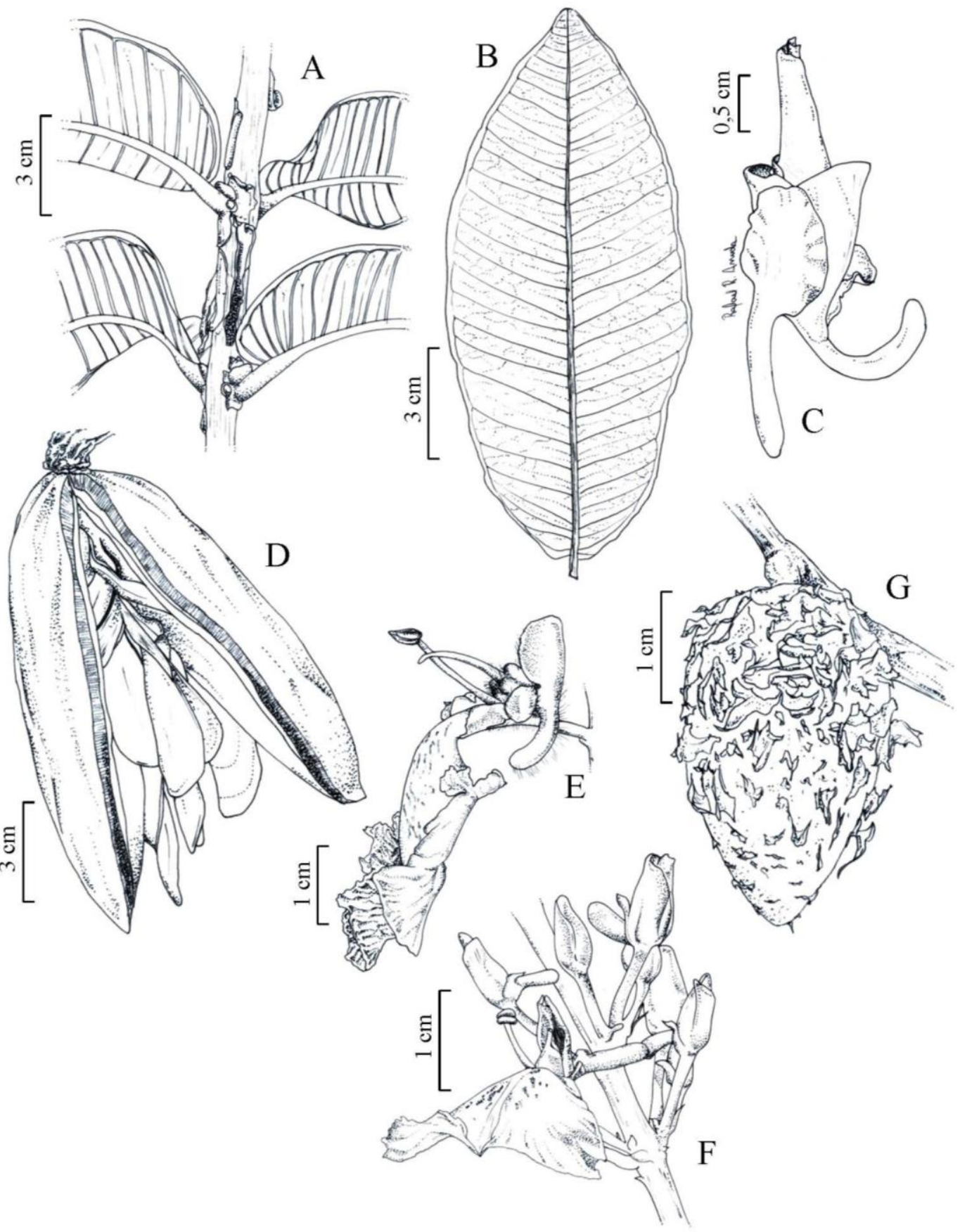

Fig. 2. A-D. Qualea grandiflora Mart. A. Ramo com casca descamante em placas; B. Folha; C. Botão floral; D. Fruto. E. Qualea multiflora Mart., flor. F-G. Qualea parviflora Mart. F. Porção da inflorescência. G. Fruto com superfície descamante. 
Flora da Serra do Cipó, Minas Gerais: Vochysiaceae

Alencar 00/379, 21.XI.2000, fl. (UEC); São José da Serra, Cipó Camping Club, M.F. Vieira \& H.S. Reis 547, 1.III.1987, fl./fr. (GUA, VIC). Santana de Pirapama: L. Krieger \& U.C. Câmara 8839, 13.VII.1970, fr. (RB); L. Krieger \& U.C. Câmara 10125, 17.II.1971, fl. (RB). Santana do Riacho: 1920'S, 4336'W, elev. 800 m, F.C.F. da Silva 156, 28.XI.1981, fl. (RB); ao longo da Rodovia Belo Horizonte - Conceição do Mato Dentro, Vale da Mãe d'Água, CFSC 9795, col. A.M. Giulietti et al., 4.V.1986, fr. (SPF, UEC); idem, R. Mello-Silva et al. 1024, 8.IV.1995, fl./fr. (SP, SPF); beira da estrada, J.A. Lombardi \& F.R.N. Toledo 198, 27.IV.1993, fl. (BHCB); estrada da Usina, área perto do Ribeirão Indequicé, CFSC 6354, col. A.M. Giulietti et al., 22.VII.1980, fl. (SPF); estrada Lagoa Santa - Conceição do Mato Dentro, A.A.A. Barbosa 385, 7.VI.1989, fr. (HUFU); Condomínio Rio Cipó, A. Costa et al. 68, 3.II.1987, fl. (RB); Hotel Monjolos, N.M. Castro 513, 13.XII.1994, fl. (HUFU); km 105, T.M. Cerati et al. 121, 08.I.1984, fl. (SP); MG-010, Cardeal Mota a Conceição do Mato Dentro, trilha dos Escravos, 1918'52,7"S, 4336'23,1"W, elev. $874 \mathrm{~m}$, G.H. Shimizu et al. 89, 25.VII.2008, fr. (UEC); Parque Nacional da Serra do Cipó, descida da Serra das Bandeirinhas, CFSC 12637, col. A.M. Giulietti et al., 28.VII.1991, fr. (SPF); Parque Nacional da Serra do Cipó, Vale Rio Cipó, 2 km E da base do IBAMA, para Serra das Bandeirinhas, CFSC 11873, col. J.R. Pirani et al., 24.III.1991, fr. (SPF); Usina Coronel Américo Teixeira, elev. 850 m, M.A. Lopes \& P.M. Andrade s.n., 25.II.1985, fl. (BHCB 8747, UEC 62895).

Qualea multiflora ocorre nos estados do DF, ES, GO, MA, MG, MS, MT, PA, PR, RO, RR, SP e TO, além do norte do Paraguai, leste da Bolívia e leste do Peru. Stafleu (1953) reconheceu duas subespécies, $Q$. multiflora subsp. multiflora e $Q$. multiflora subsp. pubescens (Mart.) Stafleu, tratando Q. jundiahy Warm. como sinônimo da segunda subespécie. As duas subespécies diferem basicamente pelo indumento castanho presente na face abaxial das folhas, râmulos, pecíolos e gemas apenas em $Q$. multiflora subsp. pubescens. Neste trabalho não consideramos essa divisão infra-específica proposta por Stafleu (1953), tratando todo o material apenas como $Q$. multiflora. Entendemos também que a sinonimização de $Q$. jundiahy sob $Q$. multiflora subsp. pubescens (Stafleu 1953) mereça ser revista, uma vez que temos constatado diferenças em relação ao tamanho da lâmina foliar (geralmente menor em Q. jundiahy), ao padrão de nervuras secundárias das folhas (maior número), arquitetura geral da árvore (geralmente mais alta, com tronco reto e copa mais arredondada), e de hábitat (floresta semidecídua para Q. jundiahy) (K. Yamamoto, obs. pess.), sugerindo que podem representar um par de espécies vicariantes.

Foi coletada em área de cerrado, com flores em quase todos os meses do ano, exceto agosto, setembro e outubro, e com frutos de fevereiro a julho e em setembro. Das espécies de Qualea que ocorrem na Serra do Cipó, assemelha-se mais a $Q$. parviflora (pela arquitetura geral da planta e pelo tamanho das folhas), mas apresenta pétala branca ou amarela, em vez de violácea, superfície da cápsula não descamante, e indumento foliar, quando presente, nunca branco-acinzentado. O tronco de $Q$. multiflora apresenta fissuras horizontais e aspecto liso, ao passo que nas demais espécies locais de Qualea, a casca do tronco é bastante espessa com fissuras longitudinais geralmente profundas.

2.4. Qualea parviflora Mart., Nov. Gen. sp. pl. 1: 135, tab. 81. 1826.

Nome vulgar: pau-terra, pau-terra-da-folha-miúda. Fig. 2 F-G

Árvores ou arbustos, 2-8 $\mathrm{m}$ alt. Ramos tortuosos, casca não descamante em placas. Gemas peruladas ovóides; estípulas subcônicas ca. 0,5 mm compr., às vezes inconspícuas. Folhas opostas ou em verticilos 3-meros; pecíolo $2-5 \mathrm{~mm}$ compr., piloso; lâmina foliar 6-11 x 1,6-3,5 cm, oblonga ou elíptica, cartácea; face adaxial pubescente a glabrescente, com tricomas concentrados principalmente na nervura primária, nervura primária impressa, secundárias promínulas; face abaxial cano-grísea tomentulosa, nervura primária proeminente, secundárias promínulas; ápice obtuso, agudo, arredondado ou emarginado; base obtusa ou arredondada; margem plana. Inflorescências terminais e axilares, 6-12,5(-23) $\mathrm{cm}$ compr., pilosas; cincinos 1-5-floros, opostos ao longo do tirso, distalmente com menos flores, pedúnculos ausentes, conferindo aspecto fasciculado aos cincinos; pedicelos 6-15 $\mathrm{mm}$ compr.; brácteas caducas; botões florais $5-10 \times 3-4 \mathrm{~mm}$, retos, ápice agudo; cálcar 6-8 × 2 mm, reto, sub-recurvo ou subincurvo, cilíndrico ou subclavado; sépala calcarada 7-8 $\mathrm{mm}$ compr.; lobos do cálice não calcarados 4-6 mm compr., ovais, ápice obtuso; pétala 1,4-1,7 x 2-2,2 cm, obcordada, violácea com manchas arroxeadas e linha central branca na face adaxial, esparsamente pilosa na porção basal da face adaxial, pilosa na porção basal da face abaxial; estame ca. $5 \mathrm{~mm}$ compr.; antera ca. $1 \mathrm{~mm}$ compr., glabra; filete ca. $4 \mathrm{~mm}$ compr.; ovário ca. $2 \times 2 \mathrm{~mm}$, globoso, tomentoso; estilete ca. 6 $\mathrm{mm}$ compr., cilíndrico, com tricomas apenas na porção basal. Cápsula 2,5-4 cm compr., oblongo-ovóide a ovóide, ápice apiculado, base arredondada a truncada, superfície verruculosa, descamante, glabra. Sementes 2 por lóculo, 25-27 x $8 \mathrm{~mm}$.

Material examinado: Jaboticatubas: $11 \mathrm{~km}$ sudoeste de São José de Almeida, em direção a Lagoa Santa, na estrada Lagoa Santa - Conceição do Mato Dentro (MG-010) e a $2,3 \mathrm{~km}$ em estrada vicinal, 1928'02"S, 4355'48"W, elev. 715 m, R. Mello-Silva et al. 2935, 13.XI.2007, fl. (SPF); caminho para o Capão dos Palmitos, CFSC 12725, col. R. Simão-Bianchini \& S. Bianchini, 31.V.1991, fr. (SPF); estrada em direção à sede do IBAMA, G.H. Shimizu et al. 213, 29.X.2008, fl. (UEC); idem, 1920'S, 4337'W, elev. 600-700 m, L.S. Kinoshita \& J.Y. Costa 00/126, 21.XI.2000, fl. (UEC); MG-020, km 56, ca. $6 \mathrm{~km}$ de Jaboticatubas, 19-34'15,8"S, 4346'05,3"W, V.C. Souza et al. 10161, 11.I.1996, fr. (ESA, SPF); Morro do Cruzeiro, flanco N do Vale do Rio Cipó, CFSC 13124, col. J.R. Pirani et al., 02.V.1993, fl. (SPF); próximo ao segundo portão depois da Sede do IBAMA, 1920'56,99"S, 4337'22"W, G.H. Shimizu \& J.G. Rando 1, 8.I.2008, fr. (UEC). Santana de Pirapama: L. Krieger \& U.C. Câmara 8792, 13.VII.1970, fr. (RB). Santana do Riacho: 1920'S, 4336'W, elev. $800 \mathrm{~m}$, O.A. Salgado 250, 28.XI.1981, fl. (RB); caminho da base do IBAMA do Rio Cipó 
para o Capão dos Palmitos, Parque Nacional da Serra do Cipó, elev. $900 \mathrm{~m}$, CFSC 11975, col. J.R. Pirani et al., 25.Ill.1991, fr. (SPF); P.T. Sano et al. 591, 22.X.1997, fl. (SPF); estrada de Cardeal Mota para Santana do Riacho, 1916'10"S, 4339'39"W, G.H. Shimizu et al. 163, 3.X.2008, fr. (UEC); estrada Lagoa Santa - Conceição do Mato Dentro, área próxima à cachoeira do hotel, A.A.A. Barbosa 353, 7.VI.1989, fr. (HUFU); A.A.A. Barbosa 386, 7.VI.1989, fl. (HUFU); Hotel Monjolos, logo atrás da sede, A. Salatino et al. 51, 25.IX.1995, fr. (SPF, UEC); idem, R. Mello-Silva et al. 1034, 9.IV.1995, fl./fr. (SP, SPF); idem, S.M.C. Guerreiro et al. 65, 20.IX.2000, fr. (UEC); km 106, Vale da Mãe d'Água, ao longo da Rodovia Belo Horizonte - Conceição do Mato Dentro, CFCR 6012, col. R.M. Harley et al., 15.XI.1984, fl. (SPF); MG-010, Cardeal Mota a Conceição do Mato Dentro, trilha dos Escravos, 1918'52,7"S, 43ํ36'23,1"W, elev. 874 m, G.H. Shimizu et al. 88, 25.VIl.2008, fr. (UEC); Usina Coronel Américo Teixeira, P.M. Andrade \& M.A. Lopes s.n., 15.IV.1985, fl. (UEC 62905).

Qualea parviflora é amplamente distribuída no Brasil (AM, BA, CE, DF, GO, MA, MG, MS, MT, PA, PI, SP e TO), Bolívia e norte do Paraguai. É uma das espécies mais características de cerrado, assim como Q. multiflora e $Q$. grandiflora.

Foi coletada em flor de abril a julho, outubro e novembro, e em fruto em quase todos os meses do ano, exceto fevereiro, agosto, novembro e dezembro. Distingue-se das outras espécies de Qualea pela pétala violácea, cápsula com superfície descamante e cujas valvas, quando completamente abertas, formam geralmente ângulo de $90^{\circ}$ com o pedicelo.

\section{Salvertia A. St.-Hil.}

3.1. Salvertia convallariodora A. St.-Hil., Mém. Mus. Hist. Nat. 6: 259. 1820.

Nome vulgar: colher-de-vaqueiro, bananeira-docampo, folha-larga.

Fig. 3 A-D

Árvores, 2,5-5 m alt.; catáfilos ausentes. Ramos cilíndricos, casca não descamante em placas. Gemas não peruladas. Folhas em verticilos 7-8-meros, congestas no ápice dos ramos florígenos; estípulas ca. $1 \mathrm{~mm}$ compr., caducas, não associadas a glândulas acessórias; pecíolo 1,5-3,5 cm compr., pubérulo; lâmina foliar (8,5-)12-22 x (4,3-)4,9-14 cm, oboval, oblonga, rigidamente coriácea; face adaxial glabra a glabrescente, nervura primária impressa, secundárias proeminentes; face abaxial glabra a glabrescente, nervuras primária e secundárias proeminentes; ápice arredondado, truncado, retuso ou emarginado, base aguda, cuneada, margem plana. Tirsos terminais, laxifloros, 22,5-40 cm compr., fulvo-pubérulas; cincinos 2-3-floros, em verticilos 7-8-meros ao longo da raque, os cincinos mais distais paucifloros e dispostos espiraladamente, pedúnculos 1,5-3 cm compr.; pedicelos $0,5-1 \mathrm{~cm}$ compr.; brácteas caducas; botões florais 2-3 $\times$ 0,6-1 cm, retos, ápice arredondado ou obtuso; cálcar 15-18 x 3-4 mm, reto ou incurvo, cilíndrico; sépala calcarada $2,3-3 \mathrm{~cm}$ compr.; lobos do cálice não calcarados 2,3-2,7 cm compr., ovais, oblongos, ápice obtuso ou arredondado; pétalas 5, brancas, 2,5-2,6 x 1-1,3 cm, subiguais, obovaloblongas, glabras; estame no plano de simetria, persistente na antese, 1,7-2,3 cm compr.; antera 1,5$1,8 \mathrm{~cm}$ compr., glabra; filete $2-5 \mathrm{~mm}$ compr.; estaminódios 2, opostos às pétalas 1 e 5 (do arranjo quincuncial), diminutos, petalóides, 2,3-3,6 x 1,4-1,7 $\mathrm{mm}$; ovário 1-3 x 3-4 mm, piramidal, tomentoso; óvulos 2 por lóculo; estilete 2-2,7 cm compr., clavado, glabro; estigma ligulado, lateral. Cápsula 3-4,5 x 1,5-2,5 cm, subovóide ou oblonga, deiscência simultânea (não basípeta) ao longo da linha de abertura no meio do lóculo, valvas reflexas separadas a partir do terço médio do fruto, sem columela central engrossada, exocarpo unido ao endocarpo, ápice obtuso ou apiculado, base truncada, marrom-pubérula ou glabrescente. Sementes 1 por lóculo, unilateralmente aladas, ca. $4 \times 1,2 \mathrm{~cm}$.

Material examinado: Conceição do Mato Dentro: $P$. Alvim \& J.E. Oliveira s.n., 14.VI.1950, fl. (VIC 3677). Jaboticatubas: $8 \mathrm{~km}$ da cidade para Conceição do Mato Dentro, pela estrada de terra mais curta, A. Salatino et al. 81, 26.IX.1995, fl./fr. (BHCB, SPF); cerca de $7 \mathrm{~km}$ da ponte do Rio das Velhas, na estrada Lagoa Santa - Jaboticatubas, $R$. Mello-Silva et al. 1021, 8.IV.1995, fl. (BHCB, SP, SPF); estrada de São José do Almeida a Jaboticatubas, $1,6 \mathrm{~km}$ do início da estrada de terra, 1927'03"S, 4348'46"W, G.H. Shimizu \& J.G. Rando 28, 12.I.2008, fr. (UEC). Santana do Riacho: Alfredinho, beira de estrada, K. Yamamoto \& A.R. Barbosa 00/21, 23.XI.2000, fl. (UEC); estrada de Cardeal Mota para Santana do Riacho, 1916'10"S, 4339'39"W, G.H. Shimizu et al. 162, 03.X.2008, fr. (UEC); estrada de Lagoa Santa a Santana do Riacho (Cardeal Mota), km 53,5, 1930'45"S, 4353'17"W, elev. 774 m, G.H. Shimizu et al. 51, 22.VII.2008, fl. (UEC); estrada Lagoa Santa - Santana do Riacho, altura do km 65, L.B. Motta et al. 7, 8.VII.2003, fr. (SPF); estrada do distrito de Cardeal Mota a Santana do Riacho, 1915'35"S, 4341'45"W, elev. 860 m, G.H. Shimizu et al. 100, 25.VII.2008, fl. (UEC); Usina Coronel Américo Teixeira, P.M. Andrade \& M.A. Lopes s.n., 15.IV.1995, fl. (UEC 63184).

Salvertia convallariodora é uma espécie típica de cerrado, que ocorre em AM, AP, BA, DF, GO, MA, MG, MS, MT, PA, PI, SP e TO, leste da Bolívia e sul do Suriname. O gênero é monotípico e apresenta grandes semelhanças morfológicas vegetativas com Vochysia seção Vochysiella subseção Decorticantes (Warm.) Stafleu, principalmente com V. rufa Mart. e $V$. cinnamomea Pohl.

$\mathrm{Na}$ área de estudo foi coletada em flor nos meses de abril, junho, julho, setembro e novembro, e em fruto nos meses de janeiro, julho, setembro e outubro. Distingue-se das demais espécies neotropicais de Vochysiaceae por apresentar corola 5mera e tirsos compostos por cincinos verticilados e não opostos, como em Qualea, ou alternos espiralados, como em Vochysia. Além disso, estruturas como pecíolo, pedúnculo, botão floral, lobos do cálice não calcarados e estaminódios possuem as maiores dimensões dentre as espécies estudadas. 
Flora da Serra do Cipó, Minas Gerais: Vochysiaceae

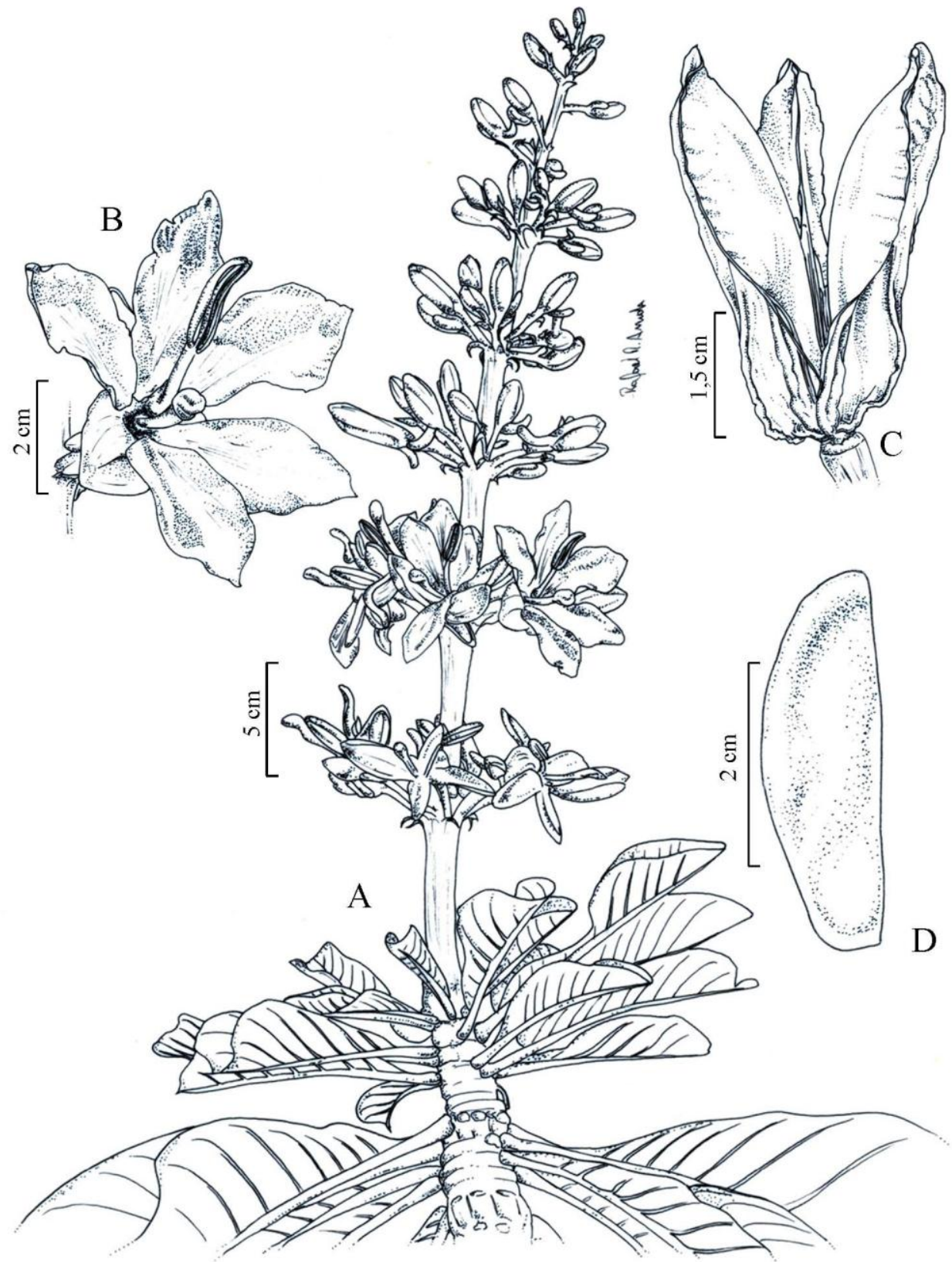

Fig. 3. A-D. Salvertia convallariodora A. St.-Hil. A. Ramo florífero; B. Flor; C. Fruto; D. Semente. 


\section{Vochysia Aubl.}

Árvores, arbustos ou subarbustos. Ramos com casca descamante em placas ou não. Gemas não peruladas; catáfilos ausentes. Folhas opostas ou verticiladas; estípulas persistentes ou caducas, não associadas a glândulas acessórias. Tirsos terminais ou terminais e subterminais ou axilares, com inflorescências parciais de cincinos dispostos espiraladamente; brácteas caducas, raramente persistentes; pétalas 3 , amarelas, desiguais, sendo a central maior, caducas na antese; estame subséssil, situado no plano de simetria, caduco na antese; estaminódios 2, opostos às pétalas laterais, diminutos, petalóides; óvulos 2 por lóculo; estigma terminal, subterminal ou lateral. Cápsula de deiscência simultânea (não basípeta) ao longo da linha de abertura no meio do lóculo, valvas fundidas ao centro do fruto em praticamente toda a extensão, sem columela central engrossada, exocarpo unido ao endocarpo. Sementes 1 por lóculo, unilateralmente aladas.

\section{Chave para as espécies}

1. Casca dos ramos descamante em placas; ovário tomentoso.

2. Folhas cartáceas, em verticilos 6-8-meros; pecíolos $2-3 \mathrm{~cm}$ compr.

10. V. rufa

2'. Folhas coriáceas, em verticilos 3-4-meros; pecíolos 2-4 mm compr.

1'. Casca dos ramos não descamante em placas; ovário glabro.

3. Pecíolos 1-3 mm compr.

4. Lâminas foliares $0,8-2 \mathrm{~cm}$ compr .

4'. Lâminas foliares com pelo menos $2,5 \mathrm{~cm}$ compr.

5. Margem foliar plana; cálcar 4-5 mm compr., subcônico

6. V. microphylla

5'.Margem foliar revoluta, raramente plana; cálcar 0,7-1 cm compr., cilíndrico

3'. Pecíolos maiores ou iguais a $4 \mathrm{~mm}$ compr.

6. Face abaxial foliar glabra.

7. Filotaxia oposta (raramente em verticilos 3-meros) 9. V. rotundifolia

7'. Filotaxia verticilada, verticilos 4(-6)-meros.

8. Lâmina foliar rigidamente coriácea, margem revoluta; cápsula 2,5-4 cm compr.

5. V. emarginata

8'. Lâmina foliar cart 12. V. thyrsoidea $2,1 \mathrm{~cm}$ compr.

13. V. tucanorum

6'. Face abaxial foliar glabrescente ou tomentosa.

9. Filotaxia oposta (raramente em verticilos 3-meros).

10. Lâminas foliares $7-7,6 \mathrm{~cm}$ larg.; inflorescência com brácteas persistentes

10'. Lâminas foliares 1,2-3,4 cm larg.; inflorescência sem brácteas persistentes.

11. Lâminas foliares 5 a 6 vezes mais compridas que largas; face abaxial foliar glabrescente próximo à nervura primária, nervuras secundárias promínulas; botões florais 1,5-2,4 cm compr.

11'. Lâminas foliares 2 a 3 vezes mais compridas que largas; face abaxial foliar ferrugíneo-tomentosa, nervuras secundárias proeminentes; botões florais 7-12 $\mathrm{mm}$ compr.

9'. Filotaxia verticilada, verticilos 4-meros.
12. Face abaxial foliar densamente ferrugíneo-tomentosa; ápice foliar emarginado; ápice do botão floral obtuso

12'. Face abaxial foliar glabrescente; ápice foliar caudado; ápice do botão flora acuminado

4.1. Vochysia acuminata Bong., Mém. Acad. Imp. Sci. Saint-Pétersbourg, Sér. 6, Sci. Math. Seconde Pt. Sci. Nat. 3(2): 5. 1839.

Nome vulgar: canela-ruiva.

Fig. $4 \mathrm{~A}$

Árvores 2-15 $\mathrm{m}$ alt. Ramos jovens quadrangulados, adultos subcilíndricos, casca não descamante em placas. Folhas opostas; estípulas 1-2 $\mathrm{mm}$ compr., caducas; pecíolo $1-2(-2,5) \mathrm{cm}$ compr., tomentoso; lâmina foliar $8-15,5 \times 1,2-3,3 \mathrm{~cm}$, lanceolado-oblonga ou lanceolada, cartácea a coriácea; face adaxial glabra, nervura primária impressa, secundárias promínulas; face abaxial glabrescente apenas próximo à nervura primária, nervura primária proeminente, secundárias promínulas; ápice gradualmente acuminado, base aguda ou cuneada, margem plana. Inflorescências terminais, $8-10 \mathrm{~cm}$ compr., ferrugíneo-tomentosas; cincinos 2-3-floros, pedúnculos ca. $1 \mathrm{~cm}$ compr.; pedicelos ca. $5 \mathrm{~mm}$ compr.; brácteas caducas; botões florais $15-24 \times 2 \mathrm{~mm}$, retos ou incurvos, cilíndricos, 
Flora da Serra do Cipó, Minas Gerais: Vochysiaceae

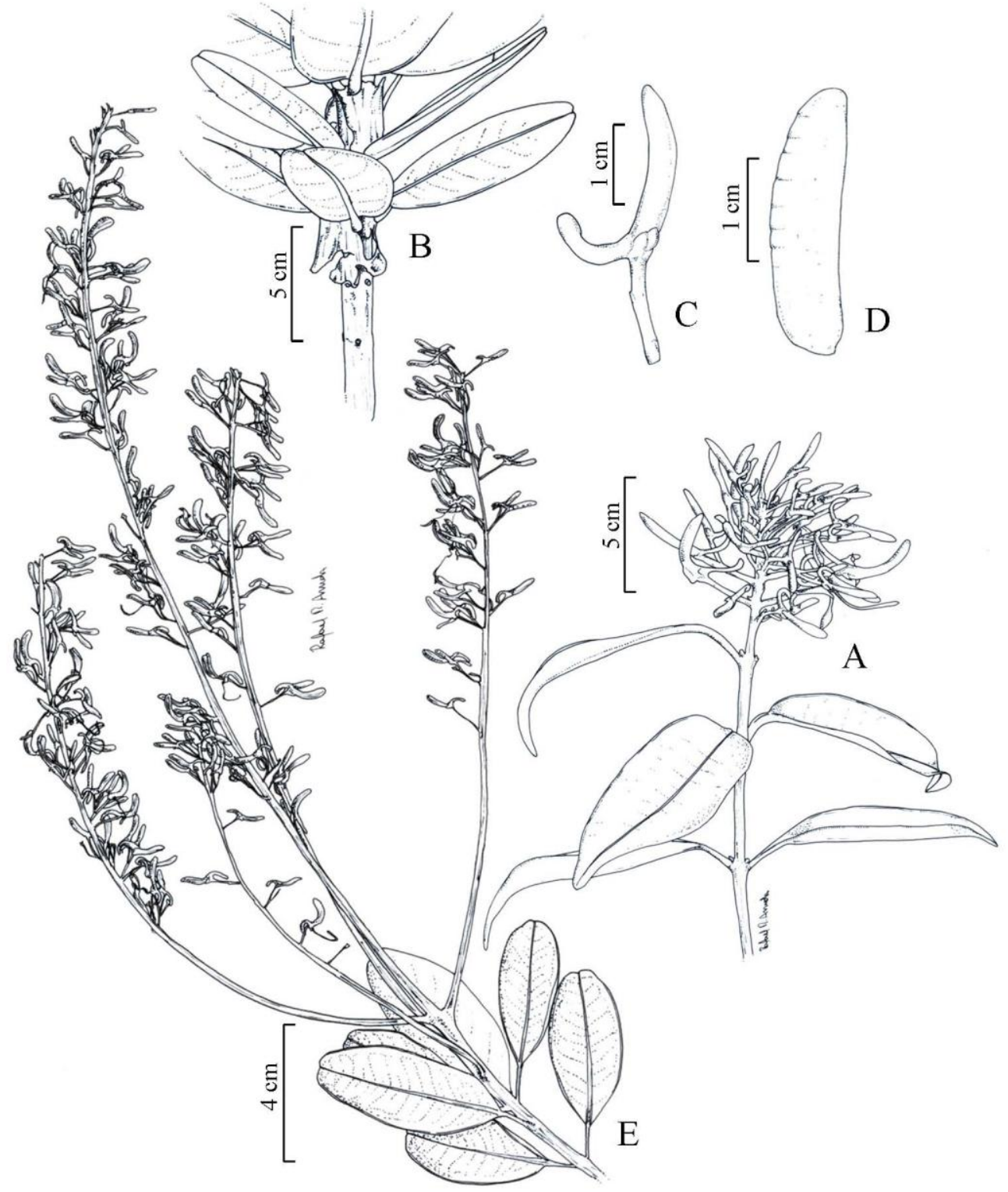

Fig. 4. A. Vochysia acuminata Bong., ramo florífero. B-D. Vochysia elliptica Mart. B. Ramo com casca descamante em placas; C. Botão floral; D. Semente. E. Vochysia emarginata (Vahl) Poir., ramo florífero. 
ápice agudo a acuminado; cálcar 7-11 x $1 \mathrm{~mm}$, incurvo ou subsigmóide, cilíndrico, ápice arredondado; sépala calcarada 1,5-2,4 cm compr.; lobos do cálice não calcarados 2-3 mm compr., ovais, ápice obtuso; pétala central 2-2,4 x 0,4 cm, pubescente apenas na região da nervura primária da face abaxial, pétalas laterais ca. 11 x 2 mm, glabras; estame 1,8-2 cm compr.; antera 1,4-1,6 cm compr., vilosa na margem e barbada na base; filete ca. $4 \mathrm{~mm}$ compr.; estaminódios ca. $1 \mathrm{x}$ $0,5 \mathrm{~mm}$; ovário ca. $2 \times 2 \mathrm{~mm}$, deltóide, glabro; estilete ca. $2 \mathrm{~cm}$ compr., cilíndrico, incurvo, glabro; estigma triangular, terminal. Cápsula 18-22 x 8-11 mm, oblonga, ápice truncado, superfície verruculosa, glabra. Sementes não vistas.

Material examinado: Congonhas do Norte: Serra Talhada (braço norte da Serra do Cipó), 11,4 km SW da estrada Congonhas do Norte - Gouveia, entrada ramificando a 3,7 km NE de Congonhas do Norte, estrada pelo alto da serra denominada localmente como "Serra do João Camilo", rumo ao vale do Rio Preto, 1851'34"S, 4345'27"W, elev. 1176 m, J.R. Pirani et al. 5190, 20.I.2004, fl./fr. (SPF, UEC). Jaboticatubas: elev. 1100-1250 m, F. Barros 360, 7.IX.1980, fl. (SP); elev. 1200 m, W. Mantovani 58, 25.VII.1979, fl. (SP); Rodovia Lagoa Santa - Conceição do Mato Dentro Diamantina, km 114, CFSC 3403, col. J. Semir \& M. Sazima, 6.IX.1972, fl. (SP, UEC); idem, km 120, CFSC 3549, col. A.B. Joly \& J. Semir, 3.XI.1972, fl. (SP, UEC); idem, km 123 , CFSC 4368, col. J. Semir et al., 3.IX.1973, fl./fr. (SP, UEC); idem, km 126, CFSC 4338, col. J. Semir et al., 3.IX.1973, fl. (SP, UEC); idem, km 127, CFSC 4717, col. J. Semir \& M. Sazima, 29.X.1973, fl./fr. (SP, UEC); mata de galeria do ribeirão Andrequicé, alguns quilômetros da rodovia no km 127, perto da Fazenda Palácio, elev. 1200 m, G. Eiten \& L.T. Eiten 6863, 24.XI.1965, fl./fr. (RB, SP); Parque Nacional da Serra do Cipó, trilha da base do IBAMA para o canyon das Bandeirinhas, P. Fiaschi et al. 60, 24.IX.1999, fl. (SPF). Santana do Riacho: afloramento entre Fazenda Palácio e estátua do Juca, K. Yamamoto \& A.R. Barbosa 00/09, 22.XI.2000, fl./fr. (UEC); Chapéu de Sol, G. Martinelli \& G. Smith 6319, 16.XII.1979, fl./fr. (RB); córrego Duas Pontinhas, A. Salatino et al. 15, 25.VI.1995, fl. (SPF); entre Chapéu de Sol e Palacinho, A.P. Duarte 6409, 25.X.1961, fl./fr. (GUA, RB); estrada da Usina, beira do rio, S.M.C. Guerreiro et al. 10, 18.IX.2000, fl. (UEC); estrada para as cachoeiras das Andorinhas e do Gavião, 19²0'39"S, 4335'38"W, G.H. Shimizu et al. 197, 04.X.2008, fl. (UEC); km 105, ao longo da Rodovia Belo Horizonte - Conceição do Mato Dentro, CFSC 6432, col. I. Cordeiro \& J.R. Pirani, 22.VIII.1980, fl./fr. (SPF, UEC); km 107, caminho para Usina Dr. Pacífico Mascarenhas, CFSC 8860, col. E. Forero et al., 7.IX.1980, fl. (SP, SPF); km 110,7, córrego Duas Pontinhas, A. Salatino et al. 75, 26.IX.1995, fl./fr. (SPF, UEC); km 115, Fazenda Palácio, lado esquerdo da estrada para Conceição do Mato Dentro, R.P. Martins et al. 265, 24.X.1980, fl./fr. (VIC); km 116, mata ciliar do córrego Duas Pontinhas, CFSC 6230, col. A. Furlan \& J.R. Pirani, 8.VI.1980, fl. (SP, SPF); km 119, mata em frente à entrada da Fazenda Palácio, CFSC 9049, col. M.L. Kawasaki \& G.L. Esteves, 16.X.1982, fl. (SPF); km 120, CFCR 5961, col. R.M. Harley et al., 14.XI.1984, fl. (SPF); Lapinha, Pico do Breu, 1910'S, 43녀'W, elev. $1126 \mathrm{~m}$, A.M.G.A. Tozzi \& L.S. Kinoshita 567, 23.XI.2000, fl./fr. (UEC); mata de galeria na parte superior do vale do Ribeirão Soberbo, 1,5 km SSE da Pensão Chapéu de Sol, 1919'S, 4335'W, elev. 1050-1150 m, CFCR 15465, col. G.L. Esteves et al., 19.IX.1990, fl. (SPF); MG-010, em direção ao Alto do Palácio, próximo à entrada da Fazenda Serra do Cipó,
1916'48"S, 4334'58"W, G.H. Shimizu et al. 105, 1.X.2008, fl. (UEC); Parque Nacional da Serra do Cipó, Serra das Bandeirinhas, elev. $1200 \mathrm{~m}$, CFSC 10522, col. C. Kameyama et al., 9.IX.1987, fl. (SP, SPF); idem, Ribeirão Mascates, próximo ao poço do Canyon das Bandeirinhas, à margem da trilha, E.L. Valente s.n., 30.IX.2006, fl. (GUA 49484, VIC 31186); próximo à Fazenda Palácio, 191'ㄷㄱ"S, 43ํ3'08"W, elev. 1120 m, G.H. Shimizu et al. 57, 23.VII.2008, fl. (UEC).

Warming (1875) considerou as espécies Vochysia acuminata Bong., V. laurifolia Warm. e V. quadrangulata Warm. muito semelhantes entre si, mas optou por mantê-las como entidades distintas. Stafleu (1948) considerou-as como uma única espécie, $V$. acuminata Bong., dividindo-a em duas subespécies: $V$. acuminata subsp. laurifolia (Warm.) Stafleu e V. acuminata subsp. quadrangulata (Warm.) Stafleu, que seria a subespécie autonímica. Apesar de contrariar o Código de Nomenclatura, Stafleu (1948) explica que preferiu o epíteto quadrangulata por razões práticas. No presente estudo, adotamos a interpretação de Vianna (1980), que separou $V$. acuminata (incluindo $V$. quadrangulata), de matas de galeria na Cadeia do Espinhaço, de $V$. laurifolia, predominantemente de matas da encosta litorânea, com base na morfologia polínica, distribuição geográfica, habitat e aspectos da lâmina foliar.

Vochysia acuminata ocorre em matas de galeria em regiões de campo rupestre, em várias áreas da porção mineira da Cadeia do Espinhaço, como Serra do Cipó, Diamantina e Grão-Mogol. Na Serra do Cipó foi coletada em flor todos os meses do ano e em fruto quase todos, exceto maio, junho e julho. Na área é uma das espécies de Vochysia mais conspícuas quando em floração, apresentando-se como árvores de grande porte com copas bem largas.

Dentre as espécies de Vochysia que ocorrem na Serra do Cipó, $V$. acuminata é semelhante a $V$. dasyantha e $V$. rectiflora. Diferencia-se de $V$. dasyantha por apresentar lâminas foliares mais estreitas, até ca. $3 \mathrm{~cm}$ de largura, e não ter grupos de brácteas persistentes ao longo da inflorescência; $V$. dasyantha apresenta lâminas foliares ca. $7 \mathrm{~cm}$ de largura e grupos de brácteas persistentes ao longo da inflorescência. Diferencia-se de $V$. rectiflora pela maior razão comprimento/largura de lâmina foliar, 5 a 6 vezes mais compridas que largas, pelas nervuras secundárias promínulas na face abaxial e por apresentar a face abaxial glabrescente apenas próximo à nervura primária; $V$. rectiflora apresenta folhas de 2 a 3 vezes mais compridas que largas, com nervuras secundárias proeminentes e indumento ferrugíneo-tomentoso na face abaxial.

4.2. Vochysia dasyantha Warm. in Mart. \& Eichler, Fl. bras. 13(2): 95. 1875.

Árvores, ca. $15 \mathrm{~m}$ alt. Ramos quadrangulados, casca não descamante em placas. Folhas opostas, raro em verticilos 3-meros; estípulas ca. $5 \mathrm{~mm}$ compr., persistentes; pecíolo 1-2,8 cm compr., tomentoso; 
Flora da Serra do Cipó, Minas Gerais: Vochysiaceae

lâmina foliar (9-)19,5-28 x 7-7,6 cm, oblonga, cartácea; face adaxial glabrescente, nervura primária impressa, secundárias planas; face abaxial tomentosa, nervuras primária e secundárias proeminentes; ápice obtusoacuminado, base obtusa ou cuneada, margem subrevoluta. Inflorescências terminais e axilares, congestas, $13-20 \mathrm{~cm}$ compr., densamente ferrugíneotomentosas; cincinos geralmente 1-floros, pedúnculos 1-2 mm compr.; pedicelos ca. $1 \mathrm{~cm}$ compr.; brácteas persistentes; botões florais 1,5-2 $\times 0,2 \mathrm{~cm}$, retos ou sub-incurvos, cilíndricos, ápice agudo; cálcar ca. $8 \times 1$ $\mathrm{mm}$, incurvo, com ápice arredondado tocando o dorso da sépala calcarada, cilíndrico; sépala calcarada ca. $2,3 \mathrm{~cm}$ compr.; lobos do cálice não calcarados 2-4 mm compr., ovais, ápice obtuso; pétala central 14-17 x 3 $\mathrm{mm}$, tomentosa apenas na face abaxial, pétalas laterais $11-12 \times 2 \mathrm{~mm}$, tomentosas apenas na face abaxial; estame ca. $1,5 \mathrm{~cm}$ compr.; antera ca. $1,1 \mathrm{~cm}$ compr., pilosa; filete ca. $4 \mathrm{~mm}$ compr.; estaminódios ca. $2,5 \times 0,5 \mathrm{~mm}$; ovário ca. $1,5 \times 1 \mathrm{~mm}$, subgloboso, glabro; estilete ca. $1,5 \mathrm{~cm}$ compr., subclavado, subincurvo, glabro; estigma triangular, plano, terminal. Cápsula e sementes não vistas.

Material examinado: Conceição do Mato Dentro: Vale do Rio Santo Antonio, A.P. Duarte 11830, 10.X.1969, fl. (BHCB); idem, J. Maria s.n., 15.X.1971, fl. (VIC 7901). Itambé do Mato Dentro: Distrito de Santana do Rio Preto (Cabeça de Boi), APA do Parque Nacional da Serra do Cipó, borda de mata ciliar, próximo à casa de José Fernandes, 1924'42"S, 4325'24"W, M.F. Santos \& E.G. Martins 153, 24.VIII.2007, fl. (SPF, UEC). Santana do Riacho: Serra do Cipó, Estrada MG010, cerca de $400 \mathrm{~m}$ antes da bifurcação entre o Morro do Pilar e Conceição do Mato Dentro, primeiro capão à $W$ da rodovia, CFSC 13525, col. M.T.V.A. Campos \& E.D.P. Souza, 20.XI.1993, fl. (SP, SPF).

Material adicional: Minas Gerais. Descoberto: Reserva Biológica da Represa do Grama, A.V. Lopes \& V.R. Scalon 26, 5.X.2001, fl. (SPF). Entre Viamão (provavelmente atual Carmésia) e Ferros: elev. 300 m, A.P. Duarte 3088, 17.IX.1950, fl. (RB).

Ocorre em Minas Gerais e Rio de Janeiro, em capões de mata e borda de matas de galeria. Há poucas coletas dessa espécie para a Serra do Cipó, com registro de floração em agosto, outubro e novembro.

A espécie é caracterizada pela inflorescência congesta, ferrugíneo-tomentosa, com grande número de brácteas persistentes e pelo cálcar incurvo, com o ápice tocando o dorso da sépala calcarada. A distinção em relação às espécies $V$. acuminata, $V$. dasyantha e $V$. rectiflora, todas da subseção Ferrugineae, estão nos comentários de $V$. acuminata. Espécie ilustrada em Vianna (2002, fig. 63).

4.3. Vochysia discolor Warm. in Mart. \& Eichler, Flor. bras. 13(2): 81. 1875.

Árvores ou arbustos, 0,5-2 $\mathrm{m}$ alt. Ramos cilíndricos, casca não descamante em placas. Folhas em verticilos 4-meros; estípulas ca. $2 \mathrm{~mm}$ compr., persistentes; pecíolo 5-15 $\mathrm{mm}$ compr., tomentoso; lâmina foliar $6,7-10 \times 3,6-5 \mathrm{~cm}$, oboval ou obovaloblonga, rigidamente coriácea; face adaxial glabrescente, exceto sobre a nervura primária, nervura primária impressa, secundárias promínulas; face abaxial densamente ferrugíneo-tomentosa, nervura primária proeminente, secundárias promínulas; ápice emarginado, base cuneada a arredondada, margem sub-revoluta a revoluta. Inflorescências terminais, laxifloras, 26-32 cm compr., ferrugíneo-pubérulas; cincinos 2-4-floros, pedúnculos 1-1,5 cm compr.; pedicelos 1-1,5 cm compr.; brácteas caducas; botões florais 2-2,5 x 0,4 cm, incurvos, subclavados, ápice obtuso; cálcar 5-7 × $1 \mathrm{~mm}$, recurvo a reto, cilíndrico, ápice globoso; sépala calcarada 3-3,3 cm compr.; lobos do cálice não calcarados ca. $2 \mathrm{~mm}$ compr., ovais, ápice obtuso; pétala central 20-35 x 4-6 mm, glabra, pétalas laterais $13-23 \times 3 \mathrm{~mm}$, glabras; estame ca. 1,8 cm compr.; antera ca. 1,3 cm compr., ciliada na margem; filete ca. $5 \mathrm{~mm}$ compr.; estaminódios ca. $1 \mathrm{x}$ $0,5 \mathrm{~mm}$; ovário ca. $2 \times 1,5 \mathrm{~mm}$, deltóide, glabro; estilete ca. $1,5 \mathrm{~cm}$ compr., cilíndrico, sub-incurvo, glabro; estigma subtrilobado, terminal. Cápsula 2,5-3,5 $x$ 1,6-1,8 cm, oblongo-ovóide, ápice mucronado, superfície verruculosa, glabra. Sementes não vistas.

Material examinado: Congonhas do Norte: Serra Talhada (braço norte da Serra do Cipó), 6,8 km SW da estrada Congonhas do Norte - Gouveia, entrada a 3,7 km NW de Congonhas do Norte, estrada pelo alto da serra denominada localmente como "Serra do João Camilo", 1848'40"S, 4345'09"W, elev. 1333 m, J.R. Pirani et al. 5130, 19.I.2004, fl. (SPF); Serra Talhada, estrada para o vale do rio Preto, 9,6 km sudoeste da estrada Congonhas do Norte Gouveia, entrada a 3,7 km noroeste de Congonhas do Norte, 1850'26"S, 4344'53"W, elev. $1304 \mathrm{~m}$, J. Lovo et al. 26, 19.I.2004, fl. (SPF).

Material adicional: Minas Gerais. Diamantina: estrada para Curralinho até $7 \mathrm{~km}$, G.J. Shepherd et al. 3974, 2.XII.1976, fl. (UEC); estrada Diamantina - Biribiri, a $7 \mathrm{~km}$ de Diamantina, CFCR 2655, col. N. Hensold et al., 2.XII.1981, fl. (UEC); Planalto de Diamantina, $4 \mathrm{~km}$ ao norte de São João da Chapada, na estrada para Inhaí, 180'ㄷㄴ"S, 434'41"W, elev. 1200 m, F. Almeda et al. 8950, 26.XI.2004, fl. (UEC). Sem localidade: $32 \mathrm{~km}$ de Gouveia para Curvelo, entrada à esquerda da Usina Eólica, Fazenda Barro Preto, estrada para torre da TELEMIG, M.D. Moraes 752, 17.VII.2005, fr. (UEC).

Essa espécie é endêmica da porção mineira da Cadeia do Espinhaço, tendo sido coletada em Diamantina, Gouveia, Serra do Cabral, Serra do Ambrósio e Serra do Cipó. Na Serra do Cipó foi encontrada apenas em campos rupestres na extrema porção norte, em Congonhas do Norte, tendo sido registrada em flor em janeiro. A maior parte dos registros de herbário de $V$. discolor é da região de Diamantina.

Vochysia discolor pertence à subseção Discolores, que é separada da subseção Lutescentes apenas por apresentar pilosidade nos râmulos adultos e na face abaxial das folhas, sendo ambas da seção Ciliantha. Devido a essa separação aparentemente artificial, $V$. discolor e $V$. thyrsoidea, muito semelhantes morfologicamente, estão cada uma numa 
subseção. Praticamente a única diferença entre essas espécies é o indumento ferrugíneo-tomentoso que cobre completamente a face abaxial das folhas em $V$. discolor, ao passo que em $V$. thyrsoidea a face abaxial é glabra (glabrescente quando jovem).

Aqui consideramos $V$. discolor e $V$. thyrsoidea como espécies distintas, mas com estudos de biossistemática ou de sistemática molecular poderão ser tratadas futuramente como uma única espécie. Espécie ilustrada em Shimizu (2009, fig. 40).

4.4. Vochysia elliptica Mart., Nov. Gen. sp. pl. 1: 141, tab. 84. 1826.

Nome vulgar: pau-doce.

Fig. 4 B-D

Subarbustos, arbustos ou árvores, 0,5-3(-5) m alt. Ramos glauco-pruinosos, cilíndricos, casca descamante em placas. Folhas em verticilos 3-4meros; estípulas ca. $1 \mathrm{~mm}$ compr., caducas; pecíolo 2$4 \mathrm{~mm}$ compr., glabro a glabrescente; lâmina foliar 4,3$7,5 \times 2,5-4,8 \mathrm{~cm}$, elíptica, oblonga ou oval, coriácea, geralmente glauco-pruinosa; face adaxial glabra, nervura primária impressa, secundárias promínulas; face abaxial glabra, nervura primária proeminente, secundárias promínulas; ápice arredondado ou obtuso, retuso ou emarginado, base arredondada ou cordada, margem sub-revoluta. Inflorescências terminais e subterminais, 9,5-29 cm compr., pubescentes; cincinos 2-3-floros, pedúnculos ca. $5 \mathrm{~mm}$ compr.; pedicelos 0,7-1 cm compr.; brácteas caducas; botões florais $14-23 \times 2 \mathrm{~mm}$, incurvos, cilíndricos, ápice agudo e acuminado; cálcar 8-10 x $1 \mathrm{~mm}$, incurvo, cilíndrico, ápice arredondado a globoso; sépala calcarada ca. $1,8 \mathrm{~cm}$ compr.; lobos do cálice não calcarados 2-4 mm compr., ovais, ápice obtuso; pétala central ca. $6 \times 2 \mathrm{~mm}$, glabra, pétalas laterais ca. 5 × $2 \mathrm{~mm}$, glabras; estame 1,7-2 cm compr.; antera 1,3-1,5 cm compr., glabra; filete 4-5 mm compr.; estaminódios ca. 0,5 × $1 \mathrm{~mm}$; ovário 2-3 × 2-3 mm, deltóide, tomentoso; estilete 1,4-2,9 cm compr., cilíndrico, incurvo, pubescente na base; estigma triangular, subterminal. Cápsula 2,6-3 x 1,5-1,7 cm, elipsóide a ovóide, ápice mucronado, superfície verruculosa, canescente-vilosa. Sementes 25-29 x 7-8 $\mathrm{mm}$.

Material examinado: Congonhas do Norte: estrada Congonhas - Gouveia, a $9 \mathrm{~km}$ de Congonhas, 1846'S, 4344'W, CFSC 8313, col. A. Furlan et al., 20.IV.1982, fl. (SPF, UEC). Jaboticatubas: alto da Serra da Lagoa Dourada, N. Roque et al. 110, 12.II.1996, fl. (SPF, UEC); estrada de terra para a sede do IBAMA, 1920'58"S, 43ำ37'07"W, elev. 809 m, M. Groppo et al. 1497, 23.IX.2007, fr. (SPF, UEC); estrada para Lagoa Dourada, cerca de $15 \mathrm{~km}$ da rodovia Lagoa Santa - Conceição do Mato Dentro, sopé da Lagoa Dourada, 1925'23"S, 433'ㄱ' et al. 107, 23.IV.2006, fl. (SPF); estrada para sede do IBAMA, G.H. Shimizu \& J.G. Rando 4, 8.I.2008, fl./fr. (UEC); estrada pelo Vale da Mãe d'Água, 19¹8'09"S, 4336'03"W, elev. 1064 m, J.R. Pirani et al. 5065, 7.III.2002, fl. (SPF, UEC); km 72, 1940'S, 4355'W, elev. $900 \mathrm{~m}$, L.B. Smith et al. 6789,
2.V.1952, fl. (GUA); km 106, Parque Nacional da Serra do Cipó, S.A.P. Godoy et al. 1782, 5.VII.1999, fl. (UEC); km 112,5, elev. $1020 \mathrm{~m}$, CFSC 1402, col. A.B. Joly et al., 15.IV.1972, fl. (UEC); km 113, CFSC 3413, col. J. Semir \& M. Sazima, 6.IX.1972, fl. (UEC); km 114, elev. $1150 \mathrm{~m}$, CFSC 25, col. A.B. Joly et al., 5.VI.1970, fl./fr. (UEC); km 115, CFSC 825, col. A.B. Joly et al., 4.III.1972, fl. (UEC); km 116, elev. 1175 m, CFSC 86, col. A.B. Joly et al., 6.VI.1970, fl. (UEC); km 142, CFSC 639, col. J. Semir et al., 6.Il.1972, fl. (UEC); Parque Nacional da Serra do Cipó, trilha da base do IBAMA para a Cachoeira da Farofa, após bifurcação para o Canyon das Bandeirinhas, P. Fiaschi et al. 64, 24.IX.1999, fl./fr. (SPF). Santa Luzia: km 131, estrada Conceição, H.L. Mello Barreto 1001, 16.IV.1935, fl. (RB). Santana de Pirapama: $L$. Krieger 10061, 17.II.1971, fl. (RB, GUA); L. Krieger \& U.C. Câmara 8844, 13.VII.1970, fl./fr. (RB); distrito de São José da Cachoeira, trilha da captação da Fazenda Toucan Cipó, 19000'22"S, 4345'20"W, elev. $680 \mathrm{~m}$, V.C. Souza et al. 32595, 17.II.2007, fl. (ESA, SPF); Fazenda Inhame, Serra Mineira, 1855'S, 4354'W, CFSC 7973, col. J.R. Pirani et al., 20.III.1982, fl. (SPF). Santana do Riacho: Alto do Curral Queimado, K. Yamamoto \& A.R. Barbosa 00/18, 23.XI.2000, bt./fr. (UEC); Alto do Palácio, M.C. Amâncio s.n., 22.IV.1990, fl. (UEC 63187); Cardeal Mota, MG-010, próx. km 101, trilha dos Escravos, L.S. Kinoshita et al. 63, 24.IX.2002, fr. (UEC); cerca de $1 \mathrm{~km}$ da base do IBAMA, próximo da Cachoeira Grande no rio Cipó, CFSC 11890, col. J.R. Pirani et al., 24.III.1991, fl. (BHCB, SPF); Chapéu de Sol, elev. $1150 \mathrm{~m}$, R.R. Ribeiro s.n., 12.V.1990, fl. (UEC 63191); córrego Duas Pontinhas, 1918'S, 4334'W, elev. 1220 m, CFSC 10341, col. J.R. Pirani et al., 22.VII.1987, fl./fr. (SPF, UEC); córrego Vitalino, CFSC 12352, J.R. Pirani et al., 31.V.1991, fl. (SPF); encosta oeste, estrada Santana do Riacho - Lapinha, 190' 17"S, 4341'41'W, elev. 1200 m, J.R. Pirani et al. 4218, 5.III.1998, fl. (SPF); escarpas rochosas voltadas para o vale do córrego da Mãe d'Água, 1919'S, 4336'W, CFSC 10311, col. J.R. Pirani et al., 21.VII.1987, fl. (SPF, UEC); estrada da Usina, em direção à Serra Morena, 1916'48"S, 43ํ36'01"W, elev. 1056 m, G.H. Shimizu et al. 77, 24.VII.2008, fl. (UEC); estrada de Cardeal Mota para Lapinha, Fazenda Paraúna, 1919'S, 433' W, K. Yamamoto \& A.R. Barbosa 00/15, 23.XI.2000, fr. (UEC); estrada de Cardeal Mota para Santana do Riacho, 1918'31"S, 4337'46"W, G.H. Shimizu et al. 153 3.X.2008, fr. (UEC); Hotel Fazenda Monjolos, N.M. Castro 492, 18.VI.1995, fl. (HUFU); km 107, caminho para Usina Dr. Pacífico Mascarenhas, CFSC 8875, col. E. Forero et al., 7.IX.1980, fl. (SP); km 107,5, A. Salatino et al. 65, 26.IX.1995, fl./fr. (SPF); km 110, córrego Vitalino, elev. $1150 \mathrm{~m}$, CFSC 13902, col. M. Sztutman et al., 5.V.1995, fl. (SPF); km 116, córrego Duas Pontinhas, CFSC 11439, col. J.R. Pirani \& M.C.P. Bonfim, 20.V.1989, fr. (SPF, UEC); km 122, $R$. Marquete et al. 48, 12.V.1987, fl./fr. (RB); km 135, A.A.A. Barbosa 360, 7.VI.1989, fl./fr. (HUFU, SPSF); Lapinha, campo rupestre na estrada próxima a entrada da subida para o afloramento, 1907'S, 43느'W, elev. 1126 m, L.S. Kinoshita \& A.O. Simões 276, 23.XI.2000, bt. (UEC); idem, contrafortes ocidentais da Serra do Cipó, elevações imediatamente a nordeste de Lapinha, nas nascentes do córrego do Boqueirão, que abastece 0 arraial, trilha para cachoeira próxima ao aqueduto, 190.6'05"S, 4340'36"W, elev. $1400 \mathrm{~m}$, L.M. Borges et al. 100, 22.IV.2006, fl. (SPF); idem, Pico do Breu, 1910'S, 4342'W, elev. 1126 m, A.M.G.A. Tozzi \& L.S. Kinoshita 589, 23.XI.2000, fr. (UEC); Parque Nacional da Serra do Cipó, descida da Serra das Bandeirinhas, CFSC 12633, col. A.M. Giulietti et al., 28.VII.1991, fl./fr. (SPF, UEC); idem, trilha da Cachoeira da Farofa, C.S. Sato \& R.S. Oliveira 54, 11.VIII.2005, fl. (SPF); Rodovia Belo Horizonte Conceição do Mato Dentro, $1200 \mathrm{~m}$ do córrego Duas Pontinhas, 1917'27"S, 433'ㄷ'"W, C.G. Gomes et al. 126, 
Flora da Serra do Cipó, Minas Gerais: Vochysiaceae

5.V.2002, fl. (SPF); idem, CFSC 13072, col. J.R. Pirani \& A.M. Giulietti, 1.V.1993, fl. (SP, SPF); subida para a estrada da Usina de Força, após a pensão Chapéu de Sol, R. Mello-Silva et al. 1027, 8.IV.1995, fl. (SP, SPF); trilha dos Escravos, 1918'51"S, 4336'26"W, elev. 868 m, G.H. Shimizu et al. 53, 22.VII.2008, fl. (UEC); idem, 1918'54"S, 4336'22"W, elev. $879 \mathrm{~m}$, G.H. Shimizu et al. 90, 25.VII.2008, fl. (UEC); Usina Coronel Américo Teixeira, P.M. Andrade \& M.A. Lopes s.n., 15.IV.1985, fl. (UEC 63186).

Vochysia elliptica é dividida em duas variedades: V. elliptica var. elliptica e V. elliptica var. firma Mart. ex Warm. Na Serra do Cipó ocorre apenas a variedade típica, que também se distribui em outras áreas da Cadeia do Espinhaço, como Grão-Mogol, Diamantina, Serra do Cabral, Chapada Diamantina (na Bahia), e em outras áreas de cerrado e/ou campo rupestre, como Serra da Canastra (MG), Chapada dos Veadeiros (GO), Caldas Novas (GO), Distrito Federal, Morro da Arnica (MT) e região sul de Tocantins. É uma das espécies mais frequentes de Vochysiaceae na Serra do Cipó, tendo sido coleta em flor em todos os meses do ano e em fruto em quase todos, menos em fevereiro, março e dezembro.

Mesmo apresentando grande plasticidade tanto em relação ao hábito - desde subarbustos a árvores - quanto a caracteres foliares como tamanho e forma, V. elliptica var. elliptica é um táxon bem delimitado e pode ser diferenciado facilmente das outras espécies de Vochysia da Serra do Cipó. O ovário tomentoso e a casca descamante em placas são estados de caráter compartilhados apenas com $V$. rufa, que também pertence à seção Vochysiella subseção Decorticantes. Essas espécies diferem, entre outras características, pelas folhas cartáceas, verticilos foliares 6-8-meros e pecíolos 2-3 cm compr. em $V$. rufa e folhas coriáceas, verticilos 3-4-meros e pecíolos 2-4 $\mathrm{mm}$ compr. em $V$. elliptica.

4.5. Vochysia emarginata (Vahl) Poir., Encycl. 8: 682. 1808.

Cucullaria emarginata Vahl, Enum. pl.: 5. 1804. Nome vulgar: congonha, caixeta, pau-de-vinho-preto. Fig. $4 \mathrm{E}$

Árvores ou arbustos, 1-4 m alt. Ramos cilíndricos, casca não descamante em placas. Folhas opostas, raramente em verticilos 3-meros; estípulas ca. $1 \mathrm{~mm}$ compr., persistentes; pecíolo ca. $1 \mathrm{~cm}$ compr., glabro; lâmina foliar 3,6-11,5 x 2,2-4,8 cm, elíptica, cartácea; face adaxial glabra, nervura primária impressa, secundárias promínulas; face abaxial glabra, nervura primária proeminente, secundárias promínulas; ápice arredondado ou obtuso, retuso, base cuneada, margem sub-revoluta. Inflorescências terminais e axilares, $16-54 \mathrm{~cm}$ compr., glabras ou pubescentes; cincinos 2-4-floros, pedúnculos ca. $5 \mathrm{~mm}$ compr.; pedicelos 5-10 mm compr.; brácteas caducas; botões florais $10-15 \times 2 \mathrm{~mm}$, retos ou incurvos, subclavados, ápice geralmente arredondado ou obtuso; cálcar 7-8 x $1 \mathrm{~mm}$, reto ou recurvo, cilíndrico, ápice arredondado a globoso; sépala calcarada ca. 1,5 cm compr.; lobos do cálice não calcarados ca. 1,5 mm compr., orbiculares, ápice obtuso; pétala central ca. 15 x $3 \mathrm{~mm}$, glabra, pétalas laterais ca. $10 \times 2 \mathrm{~mm}$, glabras; estame ca. $1,3 \mathrm{~cm}$ compr.; antera ca. $1,2 \mathrm{~cm}$ compr., ciliada na margem; filete ca. $1 \mathrm{~mm}$ compr.; estaminódios ca. $1,5 \times 0,5 \mathrm{~mm}$; ovário ca. $2 \times 2 \mathrm{~mm}$, deltóide, glabro; estilete ca. $1,1 \mathrm{~cm}$ compr., subclavado, incurvo, glabro; estigma triangular, terminal. Cápsula 1-1,5 x 0,5-1 cm, oblonga, ápice retuso a arredondado, superfície verruculosa, glabra. Sementes ca. $16 \times 5 \mathrm{~mm}$.

Material examinado: Conceição do Mato Dentro: A.P. Duarte 9638, 23.III.1966, fl. (RB). Congonhas do Norte: Serra da Carapina (Serra Talhada na folha IBGE), setor $\mathrm{N}$ da Serra do Cipó, 1852'12"S, 4344'14"W, elev. 1250 m, J.R. Pirani et al. 4113, 2.III.1998, fl. (SPF, UEC); 1856'S, 4341'W, elev. 1200 m, J.R. Pirani et al. 4183, 3.III.1998, fl. (SPF, UEC). Santana do Riacho: G. Martinelli et al. 4293, 26.IV.1977, fl. (RB); Fazenda Cachoeira da Capivara, margem do córrego da Cascalheira, M.B. Horta \& I.R. Andrade 136, 11.VII.1987, fl. (UEC); km 130, J. Maria s.n., 26.III.1971, fl. (VIC 7926); km 134, A.P. Duarte 7976, 15.III.1962, fl. (RB); km 134-135, A.P. Duarte 6468, 15.III.1962, fl. (RB); km 135, elev. 1250 m, A.P. Duarte 2627, 21.IV.1950, fl. (RB); A.P. Duarte 9623, 22.III.1966, fl. (RB); MG-010, Cardeal Mota a Conceição do Mato Dentro, $400 \mathrm{~m}$ antes da bifurcação de Conceição do Mato Dentro e Morro do Pilar, em mata do lado direito da estrada, 1913'23,4"S, 4330'05,8"W, elev. 1332 m, G.H. Shimizu et al. 67, 23.VII.2008, fl. (UEC); próximo ao córrego Três Pontinhas, 1916'00"S, 4332'49"W, elev. 1257 m, G.H. Shimizu et al. 68, 23.VII.2008, fl. (UEC); Usina Coronel Américo Teixeira, P.M. Andrade \& M.A. Lopes s.n., 15.IV.1995, fl. (UEC 62837).

Material adicional: Minas Gerais. Tiradentes: Serra de

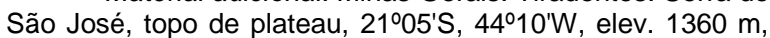
R. Alves \& J. Kolbek 893, 3.X.1989, fr. (UEC).

Vochysia emarginata ocorre na Bahia e em Minas Gerais. Na Cadeia do Espinhaço ocorre em locais como Grão-Mogol, Diamantina, Serra do Caraça, Serra do Ambrósio, Serra do Cipó e Chapada Diamantina, em bordas de mata ou capões, frequentemente associada a rios. Coletada na Serra do Cipó em flor nos meses de março a maio, julho e outubro. Das espécies de $V$. seção Ciliantha subseção Lutescentes que ocorrem na Serra do Cipó, é a única que apresenta filotaxia oposta, embora raramente possa apresentar verticilos 3-meros. Associado à filotaxia oposta, o pecíolo enegrecido e mais escuro que a lâmina e o ápice geralmente arredondado dos botões florais são característicos para o fácil reconhecimento da espécie.

4.6. Vochysia microphylla G. Shimizu \& K. Yamamoto, Phytotaxa 56: 10. 2012.

Fig. $5 \mathrm{~A}$

Arbustos, ca. 1,6 m alt., bem ramificados. Ramos cilíndricos, delgados, com estrias longitudinais 


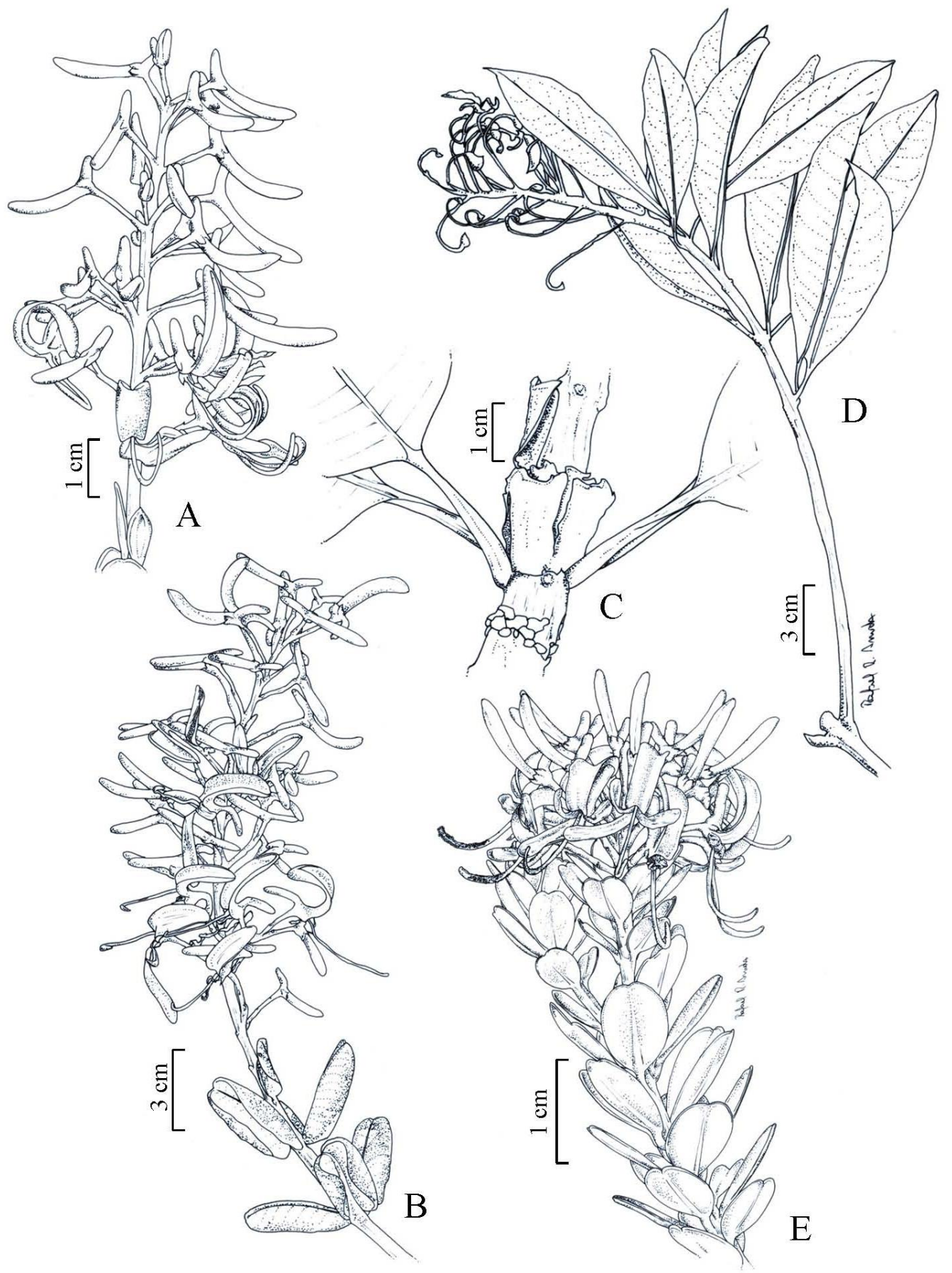

Fig. 5. A. Vochysia microphylla, ramo florífero. B. Vochysia pygmaea Bong., ramo florífero. C. Vochysia rotundifolia Mart., ramo florífero. D. Vochysia rufa Mart., ramo com casca descamante em placas. E. Vochysia schwackeana Warm., ramo florífero. 
Flora da Serra do Cipó, Minas Gerais: Vochysiaceae

nos entrenós, casca não descamante em placas. Folhas em verticilos 4(-6)-meros; estípulas ca. $1 \mathrm{~mm}$ compr., persistentes; pecíolo ca. $1 \mathrm{~mm}$ compr., glabro; lâmina foliar 8-20 x 4-12 mm, oblonga a oboval, cartácea; face adaxial glabra, nervura primária plana, secundárias promínulas; face abaxial glabra, à exceção de alguns tricomas no ápice, nervura primária proeminente, secundárias promínulas; ápice retuso; base arredondada a cuneada; margem plana. Inflorescências terminais, congestas, $3-3,5 \mathrm{~cm}$ compr., pubescentes; cincinos 2-3-floros, pedúnculos ca. $5 \mathrm{~mm}$ compr.; pedicelos 3-7 mm compr.; brácteas caducas; botões florais $10-12 \times 1,5-2 \mathrm{~mm}$, retos a sub-incurvos, cilíndricos, ápice agudo a acuminado; cálcar 3-5 × 1 $\mathrm{mm}$, reto ou incurvo, cilíndrico, ápice globoso; sépala calcarada 1-1,1 cm compr.; lobos do cálice não calcarados ca. $2 \mathrm{~mm}$ compr., ovais, ápice obtuso; pétala central 5-8 x 1-2 mm, glabra, pétalas laterais 4$6 \times 1 \mathrm{~mm}$, glabras; estame 1-1,1 cm compr.; antera ca. $8 \mathrm{~mm}$ compr., glabra; filete 2-3 mm compr.; estaminódios ca. 0,5 x 0,6 mm; ovário 1-2 × 1,5 mm, deltóide, glabro; estilete 8,5-15 mm compr., cilíndrico, reto a incurvo, glabro; estigma subtriangular, subterminal. Cápsula 2-2,3 x 1,1-1,3 cm, ovóide a oblongo-ovóide, ápice subtruncado ou arredondado, superfície verruculosa, glabra. Sementes ca. $22 \times 7$ $\mathrm{mm}$.

Material examinado: Itambé do Mato Dentro: Santana do Rio Preto, Cabeça de Boi, L.M. Borges \& M.F. Santos 279 17.XII.2007, fl. (SPF). Morro do Pilar: Parque Nacional da Serra do Cipó, Alto do Palácio, 19¹5'S, 4331'W, elev. 1400 $\mathrm{m}$, L.C. Rodrigues 81, 16.XI.2007, fl. (BHCB, UEC); MG-010, Cardeal Mota a Conceição do Mato Dentro, trilha para as velózias gigantes, 1914'48"S, 4330'42"W, elev. $1256 \mathrm{~m}$, G.H. Shimizu et al. 62, 23.VII.2008, fr. (UEC); idem, G.H. Shimizu et al. 137, 2.X.2008, bt./fr. (UEC); idem, G.H. Shimizu et al. 201, 28.X.2008, bt. (UEC); idem, G.H. Shimizu 231, 14.V.2010, fl./fr. (UEC).

Esta espécie assemelha-se muito a uma miniatura de $V$. thyrsoidea, principalmente no formato das folhas, flores e frutos, porém com dimensões reduzidas. Suas folhas não ultrapassam $2 \mathrm{~cm}$ compr., enquanto as de $V$. thyrsoidea, na Serra do Cipó, geralmente apresentam pelo menos $7 \mathrm{~cm}$ compr. Também é próxima de $V$. pygmaea, que pode apresentar hábito arbustivo. São facilmente distintas pelo número de folhas nos verticilos, geralmente quatro em $V$. microphylla e três em $V$. pygmaea, pelas dimensões das folhas, sempre menores em $V$. microphylla, e pela inflorescência mais longa em $V$. pygmaea (8-40 cm compr.). Até o momento é conhecida apenas por poucos indivíduos, ocorrendo em campo rupestre nos municípios de Morro do Pilar e Itambé do Mato Dentro, provavelmente sendo endêmica da Serra do Cipó. E um arbusto bastante ramificado com cerca de 1,6 $\mathrm{m}$ de altura, de aspecto cespitoso. Foi coletada em flor em maio, novembro e dezembro e em fruto em maio, julho e outubro.
4.7. Vochysia pygmaea Bong., Mém. Acad. Imp. Sci. Saint-Pétersbourg, Sér. 6, Sci. Math. Seconde Pt. Sci. Nat. 3(2): 7, tab. 4. 1839.

Vochysia martiana Stafleu, Recueil Trav. Bot. Néerl. 41(2): 478. 1948, syn. nov.

Fig. $5 \mathrm{~B}$

Subarbustos ou arbustos, 0,3-1(-2) m alt. Ramos cilíndricos, casca não descamante em placas. Folhas em verticilos 3-meros, raramente 4-5-meros; estípulas ca. $1 \mathrm{~mm}$ compr., persistentes; pecíolo 2-3 $\mathrm{mm}$ compr., glabro; lâmina foliar 2,5-3,7 x 1,6-3 cm, elíptica, elíptico-oboval a oboval, às vezes oblonga, rigidamente coriácea; face adaxial glabra, nervura primária impressa, secundárias levemente impressas, quase inconspícuas; face abaxial glabra, nervura primária proeminente, secundárias promínulas; ápice agudo ou obtuso, retuso ou emarginado, base aguda ou obtusa, margem plana. Inflorescências terminais, laxifloras, 8-40 cm compr., glabras; cincinos 2-4-floros, pedúnculos 4-7 $\mathrm{mm}$ compr.; pedicelos 7-10 $\mathrm{mm}$ compr.; brácteas caducas; botões florais 15-25 × 2 $\mathrm{mm}$, incurvos, cilíndricos, ápice agudo; cálcar 4-5 x 1-2 $\mathrm{mm}$, reto ou sub-recurvo, subcônico, ápice arredondado; sépala calcarada 1,5-2,1 cm compr.; lobos do cálice não calcarados 2-3 mm compr., ovais, ápice obtuso; pétala central ca. $26 \times 2 \mathrm{~mm}$, ciliada nas margens e na porção apical, pétalas laterais ca. $14 \times 1$ $\mathrm{mm}$, ciliadas nas margens e na porção apical; estame ca. 2,5 cm compr.; antera ca. 1,5 cm compr., glabra; filete ca. $1 \mathrm{~cm}$ compr.; estaminódios ca. 2 × 0,5 mm; ovário ca. $2 \times 2 \mathrm{~mm}$, deltóide, glabro; estilete $2-3,2 \mathrm{~cm}$ compr., subclavado, incurvo, glabro; estigma capitado, terminal a subterminal. Cápsula 1,8-2 x 1,2-1,3 cm, elipsóide a ovóide, ápice emarginado, superfície verruculosa, glabra. Sementes ca. $2 \times 0,6 \mathrm{~cm}$.

Material examinado: Jaboticatubas: A.R. Barbosa s.n., 15.I.1996, fl. (UEC 81912); J. Vasconcellos et al. s.n., 9.IX.1987, fr. (UEC 46997); elev. 1200 m, W. Mantovani 51, 25.VII.1979, fr. (SP); em direção a Serro, V.S. Fonseca \& G. Krull 388, II.1996, fl. (RB); estrada da Usina, CFSC 2234, col. A.B. Joly et al., 28.V.1972, fl./fr. (UEC); Rodovia Lagoa Santa - Conceição do Mato Dentro - Diamantina, km 112, CFSC 699, col. J. Semir \& M. Sazima, 7.II.1972, fl. (UEC); idem, km 114, CFSC 3663, col. A.B. Joly \& J. Semir, 4.XI.1972, fl. (UEC); idem, km 115, CFSC 596, col. J. Semir \& M. Sazima, 15.XII.1971, fl./fr. (UEC); idem, km 116, elev. 1175 m, CFSC 133, col. A.B. Joly et al., 6.VI.1970, fr. (UEC); idem, km 120, S.A.P. Godoy et al. 1632, 16.I.1999, fl. (SPFR); idem, km $121,19^{\circ} 18^{\prime} \mathrm{S}, 43^{\circ} 35^{\prime} \mathrm{W}$, elev. $1200 \mathrm{~m}$, G. Eiten \& L.T. Eiten 6888, 25.XI.1965, fl. (SP); idem, km 122, CFSC 559, col. J. Semir \& M. Sazima, 14.XII.1971, fl./fr. (UEC); trilha para a Cachoeira da Farofa, próximo à sede do IBAMA, 1922'46"S, 4334'34"W, elev. 838 m, M. Groppo et al. 1466, 22.IX.2007, fl. (UEC). Lagoa Santa: F. Segadas-Vianna \& J. Lorêdo Jr. s.n., 1953, fl. (RB 117725). Santa Luzia: km 122, H.L. Mello Barreto 1002, 14.IV.1935, fl./fr. (RB); km 127, H.L. Mello Barreto 7108, 12.I.1934, fl./fr. (F, isótipo de V. martiana). Santana do Riacho: J.R. Stehmann et al. s.n., 19.V.1990, fr. (UEC 62840); a 5 km da Pensão Chapéu de Sol, G.H. 
Shimizu \& J.G. Rando 17, 10.I.2008, fl. (UEC); afloramento entre Fazenda Palácio e estátua do Juca, K. Yamamoto \& A.R. Barbosa 00/12, 22.XI.2000, fl. (UEC); ao longo da estrada nos arredores do córrego Alto do Cupim e córrego Duas Pontinhas, cerca de 3,5-4,5 km NE da pensão Chapéu de Sol (NNE Cardeal Mota), 41-42 km E de Baldim, 1917'S, 4334'W, elev. 1180-1250 m, CFCR 15476, col. G.L. Esteves et al., 20.IX.1990, fl. (SPF); Cardeal Mota a Conceição do Mato Dentro, área do Geraldinho, 1917'11"S, 433ํ'15"W, elev. 1210 m, G.H. Shimizu et al. 87, 24.VII.2008, fr. (UEC); Chapéu de Sol, I. San Martin-Gajardo et al. s.n., 3.II.1998, fl. (UEC 114451); córrego Duas Pontinhas, 1918'S, 433' W, elev. 1220 m, CFSC 10342, col. R. Mello-Silva et al., 22.VII.1987, fl./fr. (SPF, UEC); estrada de São José de Almeida a Conceição do Mato Dentro, elev. 1250 m, C.E.B. Pereira 342, 26.XI.1998, fl. (GUA); estrada Lagoa Santa Conceição do Mato Dentro, A.A.A. Barbosa 346, 8.VI.1989, fl. (HUFU); estrada para Lapinha, elev. $1090 \mathrm{~m}$, CFSC 7929 , col. W. Mantovani et al., 18.II.1982, fl./fr. (SP, SPF, UEC); km 103-104, ao longo da rodovia Belo Horizonte - Conceição do Mato Dentro, elev. 1100 m, G. Martinelli 4316, 26.IV.1978, fl./fr. (RB); km 106, elev. 1000 m, G. Martinelli et al. 11331, 21.I.1986, fl. (RB); km 109 (antigo 114), C.M. Sakuragui \& V.C. Souza 35, 2.VIII.1990, fl./fr. (ESA, SPF); idem, elev. 1100-1250 m, CFSC 8700, col. E. Forero et al., 6.IX.1980, fr. (SP); idem, elev. 1200-1350 m, T. Wendt et al. 82, 1.Il.1987, fl. (RB); km 111, T.M. Cerati et al. 110, 7.I.1984, fl. (SP); km 114, N.M. Castro s.n., 31.X.1993, fl. (HUFU 5004); km 116 , córrego Duas Pontinhas, CFSC 11440, col. J.R. Pirani \& M.C.P. Bonfim, 20.V.1989, fr. (SPF, UEC); km 117, próximo ao córrego Duas Pontinhas, CFSC 9384, col. A.M. Giulietti et al., 31.XI.1985, fl. (UEC); km 119, CFSC 9183, col. M.G. Arrais et al., 6.XI.1983, fl./fr. (SPF); idem, Fazenda Palácio, CFSC 6829, col. J.R. Pirani et al., 15.XII.1980, fl. (SPF, UEC); km 120, CFCR 5969, col. B. Stannard et al., 14.XI.1984, fl. (UEC); km 124 antigo, CFSC 6819, col. J.R. Pirani et al., 15.XII.1980, fl. (SP); km 127, elev. 1200 m, G. Martinelli 2626, 16.VII.1977, fl. (RB); MG-010, 1920'S 4337'W, elev. $1300 \mathrm{~m}$, G.C.P. Pinto 79/82, 21.V.1982, fl./fr. (RB); MG-010, com vista para a Pedra do Elefante, G.H. Shimizu et al. 202, 28.X.2008, fl. (UEC); idem, G.H. Shimizu et al. 205, 28.X.2008, fl. (UEC); idem, G.H. Shimizu et al. 206, 28.X.2008, fl. (UEC); idem, G.H. Shimizu et al. 207, 28.X.2008, fl. (UEC); próximo ao Chapéu de Sol, R.P. Martins et al. 263, 24.X.1980, fl. (VIC); Serra da Lapinha, maciço NW da Serra do Cipó, próximo à localidade da Lapinha, a cerca de $50 \mathrm{~km}$ da Rodovia Belo Horizonte - Conceição do Mato Dentro, elev. 1000 m, CFSC 12200, col. J.R. Pirani et al., 27.III.1991, fr. (SPF). Sem localidade: A.B. Joly 1099, 17.I.1951, fl. (SP); A. Giani s.n., 24.XI.1984, fl. (UEC 62842); A. Macedo s.n., 1962, fl. (OUPR 21810); H.F. Leitão Filho s.n., 28.XII.1973, fl. (IAC 24130); J. Badini \& H.L.M. Barreto s.n., 1938, fl. (OUPR 21809); J.G. Kuhlmann \& L. Edmundo Paes s.n., 16.I.1951, fl. (RB 73002); M.A. Lisboa s.n., 18.VII.1971, fl. (OUPR 21807); km 117, J. Maria s.n., 13.III.1972, fl./fr. (VIC 7906); km 120 a 134, elev. 1000 a 1200 m, A.P. Duarte 2008, 8.XII.1949, fl. (RB); km 131, P. Occhioni s.n., 4.XII.1940, fl. (RB 44195); Parque Nacional da Serra do Cipó, L.D. Meireles et al. 901, 28.II.2002, fl. (UEC).

Material adicional: Minas Gerais. Diamantina: Estrada Diamantina - Serro, elev. 900 m, G. Martinelli \& G. Smith 6314, 15.XII.1979, fl. (RB).

Vochysia pygmaea é uma espécie praticamente restrita à Serra do Cipó, só havendo uma única coleta de outra localidade, Diamantina $(R B, G$. Martinelli \& G. Smith 6314). Geralmente são subarbustos de pequeno porte, que ocorrem em campo rupestre. É uma espécie muito frequente de Vochysia na Serra do Cipó, tendo sido coletada em flor todos os meses do ano e em fruto quase todos, exceto janeiro e outubro.

Da espécie mais proximamente relacionada, $V$. rotundifolia, com a qual compartilha hábito subarbustivo ou arbustivo e verticilos 3-meros (raramente 4-5-meros em $V$. pygmaea), distingue-se pela lâmina foliar elíptica, elíptico-oboval a oboval, às vezes oblonga, pela margem foliar sempre plana, e pelo cálcar 4-5 mm compr., subcônico, ao passo que em $V$. rotundifolia a lâmina foliar é orbicular ou amplamente oval, a margem foliar é geralmente revoluta e o cálcar cilíndrico varia de 7 a $10 \mathrm{~mm}$ compr. Vochysia pygmaea também é próxima de $V$. microphylla. Comentários sobre a separação entre essas duas espécies são apresentados em $V$. microphylla.

Stafleu (1948) descreveu V. martiana Stafleu como uma espécie endêmica da Serra do Cipó, próxima a $V$. pygmaea, separando-as pela lâmina foliar elíptica e ápice agudo-obtuso em $V$. pygmaea e lâmina foliar oboval e ápice truncado e retuso em $V$. martiana. Analisando as fotos dos tipos dessas espécies e suas descrições, além da observação no campo e de espécimes de coleção, constatamos uma grande variação morfológica para $V$. pygmaea, que abrange as características supostamente diagnósticas de $V$. martiana. Sendo assim, propomos que $V$. martiana seja sinonimizada com $V$. pygmaea.

4.8. Vochysia rectiflora Warm. in Mart. \& Eichler, Fl. bras. 13 (2): 96.1875.

Nome vulgar: canela-ruiva, murici.

Árvores, ca. $20 \mathrm{~m}$ alt. Ramos jovens quadrangulados, adultos subcilíndricos, casca não descamante em placas. Folhas opostas; estípulas ca. $1 \mathrm{~mm}$ compr., persistentes; pecíolo 1-1,5 cm compr., pubescente; lâmina foliar 8,4-10 x 2,6-3,4 cm, oblonga, cartácea a coriácea; face adaxial glabra, nervura primária impressa, secundárias planas; face abaxial ferrugíneo-tomentosa, nervuras primária e secundárias proeminentes; ápice abrupta a gradualmente acuminado, base obtusa a aguda; margem plana. Inflorescências terminais e axilares, congestas, ca. 10 $\mathrm{cm}$ compr., tomentosas; cincinos (1-)2(-3)-floros, pedúnculos ca. $3 \mathrm{~mm}$ compr.; pedicelos $3-4 \mathrm{~mm}$ compr.; brácteas caducas; botões florais 7-12 $\times 2 \mathrm{~mm}$, retos, cilíndricos, ápice acuminado; cálcar 5-8 × $1 \mathrm{~mm}$, incurvo ou sub-incurvo, cilíndrico, ápice globoso; sépala calcarada 1,3-1,8 cm compr.; lobos do cálice não calcarados 1-2 mm compr., ovais, ápice obtuso; pétala central ca. $12 \times 2 \mathrm{~mm}$ compr., levemente adpresso-pilosa na região da nervura primária na face abaxial, pétalas laterais ca. $6 \times 1,5 \mathrm{~mm}$ compr., glabras; estame ca. 1,1 cm compr.; antera ca. $7 \mathrm{~mm}$ compr., vilosa, barbada na base; filete ca. $4 \mathrm{~mm}$ compr.; estaminódios ca. 1 x 0,5 mm; ovário ca. 1 x $1,5 \mathrm{~mm}$, deltóide, glabro; estilete ca. $1,1 \mathrm{~cm}$ compr., 
Flora da Serra do Cipó, Minas Gerais: Vochysiaceae

cilíndrico, glabro; estigma capitado, terminal. Cápsula e sementes não vistas.

Material examinado: Sem localidade: Serra do Cipó, M.A. Lisboa s.n., VII.1972, fl. (OUPR 21972).

Material adicional: Minas Gerais. Fervedouro: córrego Água Limpa, $20^{\circ} 46^{\prime}$ S, $42^{\circ} 21^{\prime} \mathrm{W}$, L.S. Leoni 2339, 2.XI.1993, fl. (GUA). Lima Duarte: São José dos Lopes, Fazenda da Serra, grota da Limeira, V.C. Almeida 187, I.1996, fl. (GUA); V.C. Almeida s.n., 1995, fl. (GUA 43714). Sem localidade: Sítio Balbino, E.P. Heringer 2834, 1.XI.1946, fl. (GUA). Rio de Janeiro. Teresópolis: estrada Teresópolis - Itaipava, № 3003 , condomínio Green Village, km 29, C.A.L. Oliveira et al. 1386, 29.X.1997, fl. (GUA).

Vochysia rectiflora ocorre em regiões de mata no Espírito Santo, em Minas Gerais e no Rio de Janeiro. É dividida em duas variedades: V. rectiflora Warm. var. rectiflora e $V$. rectiflora var. glabrescens Warm., que difere da forma típica basicamente pelo indumento menos desenvolvido. Na Serra do Cipó ocorre somente a variedade típica, que foi coletada em flor no mês de julho.

É muito semelhante a $V$. acuminata, mas apresenta a face abaxial das folhas ferrugíneotomentosa, em vez de glabrescentes próximo à nervura primária, e as nervuras secundárias proeminentes na face abaxial, em vez de promínulas. Além disso, a razão comprimento/largura da lâmina foliar é maior em $V$. acuminata, cerca de 5 a 6/1, ao passo que em $V$. rectiflora é cerca de 2 a $3 / 1$. Os botões florais, 7-12 mm compr., e a antera, ca. $7 \mathrm{~mm}$ compr., de $V$. rectiflora são menores em comparação com $V$. acuminata, que tem botões 1,5-2,4 cm compr. e antera 1,4-1,6 cm compr.

4.8. Vochysia rotundifolia Mart., Nov. Gen. sp. pl. 1: 140 , tab. 83. 1826.

V. cipoana Stafleu, Act. Bot. Neerl. 3: 409. 1954, syn. nov.

Fig. $5 \mathrm{C}$

Subarbustos ou arbustos, 1,5-2,5(-5) m alt. Ramos subcilíndricos, delgados, virgados, casca não descamante em placas. Folhas em verticilos 3-meros; estípulas ca. $1 \mathrm{~mm}$ compr., persistentes; pecíolo ca. 1 mm compr., glabro; lâmina foliar 3,5-5(-10) x 3-4,4(-6) $\mathrm{cm}$, geralmente orbicular ou amplamente oval, rigidamente coriácea; face adaxial glabra, nervura primária impressa, secundárias proeminentes; face abaxial glabra, nervura primária proeminente, secundárias planas; ápice arredondado ou emarginado; base arredondada ou cordada; margem revoluta ou mais raramente plana. Inflorescências terminais, laxifloras, 4,5-16,5(-20) cm compr., glabras; cincinos 24-floros, pedúnculos ca. $1 \mathrm{~cm}$ compr.; pedicelos ca. 1 cm compr.; brácteas caducas; botões florais 14-23 x 2$3 \mathrm{~mm}$, retos ou incurvos, cilíndricos, ápice obtuso; cálcar 7-10 x $1 \mathrm{~mm}$, reto ou recurvo, cilíndrico, ápice arredondado;sépala calcarada 2,3-4 cm compr.; lobos do cálice não calcarados 1-1,5 mm compr., ovais, ápice obtuso; pétala central 17-21 x 1-2 mm compr., ciliada nas margens; pétalas laterais 7-10 $\times 1$ $\mathrm{mm}$ compr., ciliadas nas margens; estame 1,8-1,9 cm compr.; antera ca. $1,5 \mathrm{~cm}$ compr., glabra ou ciliada; filete 3-4 mm compr.; estaminódios ca. 1,5 x 0,5 mm; ovário 1-2 x $2 \mathrm{~mm}$, deltóide, glabro; estilete 2,2-4,4 cm compr., clavado, glabro; estigma capitado, lateral. Cápsula 12-15 x 5-8 mm, oblongo-ovóide, ápice subtruncado, superfície verruculosa, glabra. Sementes não vistas.

Material examinado: Jaboticatubas: Rodovia Lagoa Santa - Conceição do Mato Dentro - Diamantina, km 127, CFSC 2639, col. J. Semir \& M. Sazima, 19.VII.1972, fl./fr. (SP); idem, km 128, CFSC 2966, col. A.B. Joly \& J. Semir, 20.VIII.1972, fl. (SP, UEC). Morro do Pilar: MG-010, Cardeal Mota a Conceição do Mato Dentro, trilha para as velózias gigantes, 1914'50,4"S, 4330'33,1"W, elev. $1256 \mathrm{~m}$, G.H. Shimizu et al. 61, 23.VII.2008, fl. (UEC). Santana de Pirapama: Distrito de São José da Cachoeira, trilha do João Carrinho, 1902'53"S, 4344'19"W, elev. 756-1080 m, V.C. Souza et al. 32701, 18.II.2007, fl. (SPF). Santana do Riacho: Rodovia Belo Horizonte - Conceição do Mato Dentro, km 118 atual (antigo 125), APA Morro da Pedreira, 1915'38"S, 4333'10"W, elev. $1254 \mathrm{~m}$, J.R. Pirani et al. 5014, 5.III.2002, fl. (SPF, UEC); idem, km 124, Alto do Palácio, curva da estrada ao Sul da estátua do velho Juca, CFSC 12354, col. J.R. Pirani et al., 31.V.1991, fl./fr. (SPF); idem, km 131, próximo Hotel Palacinho, E. Pereira 2908, 7.IV.1957, fl. (RB); idem, km 134, A.P. Duarte 6513, 15.III.1962, fl. (RB); idem, km 134 (antigo), A.P. Duarte 11374, 11.II.1969, fl. (BHCB); idem, km 135, A.P. Duarte 9624, 23.III.1966, fl. (RB); estrada para Conceição do Mato Dentro, E. Costa 358, 26.II.1984, fl. (RB). Sem localidade: km 135, elev. 1250 m, A.P. Duarte 2626, 21.IV.1950, fl. (L, holótipo, e RB, isótipo, de V. cipoana); C.E.B. Pereira 344, 27.III.1998, fl. (GUA); J. Maria s.n., 13.Il.1971, fl. (VIC 7923).

Material adicional: Minas Gerais. Diamantina: Cerca de $2 \mathrm{~km}$ de São João da Chapada, elev. $1200 \mathrm{~m}$, H.S. Irwin et al. 28375, 26.III.1970, fl. (RB).

Vochysia rotundifolia é praticamente restrita à Serra do Cipó, com exceção de uma única coleta de outra localidade, Diamantina (RB, H.S. Irwin et al. 28375). Ocorre em campo rupestre, entre afloramentos rochosos. Foi coletada em flor de fevereiro a maio e de julho a agosto, e em fruto em maio e julho. É bem distribuída em toda a Serra do Cipó, mas não é abundante, ocorrendo sempre em pequenas populações. É caracterizada pelos ramos subcilíndricos, virgados, e principalmente pelas folhas geralmente orbiculares de margem revoluta. Comentários sobre a separação entre $V$. rotundifolia e $V$. pygmaea são apresentados em $V$. pygmaea.

Ao examinar o isótipo, foto do holótipo e a descrição original de Vochysia cipoana, tratada até então como endêmica da Serra do Cipó (Stafleu 1954), não foram encontradas características distintivas entre essa espécie e $V$. rotundifolia. Desse modo, optamos por tratar $V$. cipoana como sinônimo de $V$. rotundifolia. 
4.10. Vochysia rufa Mart., Nov. Gen. sp. pl. 1: 144, tab. 86. 1826.

Nome vulgar: pau-doce.

Fig. $5 \mathrm{D}$

Árvores 2,5-3 m alt. Ramos subcilíndricos, casca descamante em placas. Folhas em verticilos 6 8-meros, congestos no ápice dos ramos florígenos; estípulas ca. $1 \mathrm{~mm}$ compr., caducas; pecíolo $2-3 \mathrm{~cm}$ compr., rufo-tomentoso; lâmina foliar 11,5-14,5 x 6,5-7 $\mathrm{cm}$, ovada, oblonga ou elíptica, cartácea; face adaxial glabra, nervura primária plana, secundárias promínulas; face abaxial tomentosa, nervuras primária e secundárias proeminentes; ápice retuso ou emarginado, base aguda ou cuneada, margem subrevoluta. Inflorescências terminais, $13,5-32 \mathrm{~cm}$ compr., densamente ferrugíneo-tomentosas; cincinos 2-4floros, pedúnculos ca. $5 \mathrm{~mm}$ compr.; pedicelos ca. 5 mm compr.; brácteas caducas; botões florais 14-20 × 2 $\mathrm{mm}$, incurvos, cilíndricos, ápice obtuso a arredondado; cálcar 5-6 x 1 mm, incurvo, cilíndrico, ápice arredondado; sépala calcarada $1,2-1,5 \mathrm{~cm}$ compr.; lobos do cálice não calcarados ca. $2 \mathrm{~mm}$ compr., orbiculares, ápice obtuso; pétala central ca. $12 \times 6$ $\mathrm{mm}$, glabra, pétalas laterais ca. $8 \times 4 \mathrm{~mm}$, glabras; estame ca. 1,2 cm compr.; antera ca. $1 \mathrm{~cm}$ compr., glabra; filete ca. $2 \mathrm{~mm}$ compr.; estaminódios ca. $1 \mathrm{x}$ $0,5 \mathrm{~mm}$; ovário ca. $3 \times 3 \mathrm{~mm}$, subgloboso, tomentoso; estilete ca. 1,8 cm compr., subclavado, glabro; estigma subtrilobado, lateral a subterminal. Cápsula 3,5-4,5 x 2,2-2,5 cm, oblongo-ovóide, ápice mucronado, superfície verruculosa, canescente-vilosa. Sementes ca. $3,5 \times 1,2 \mathrm{~cm}$.

Material examinado: Jaboticatubas: T.S.M. Grandi et al. 1418, 18.V.1983, fl. (BHCB). Sem localidade: Cerrado entre Lagoa Santa e Serra do Cipó, A.P. Duarte 6474, 16.III.1972, fl. (RB); Sertão entre Lagoa Santa e Serra do Cipó, A.P. Duarte 2436, 14.IV.1950, fl. (RB).

Material adicional: Minas Gerais. Umuarama: 160' S, 4626'W, elev. $955 \mathrm{~m}$, C. Proença et al. 2314, 27.XI.2000, fr. (UEC). Sem localidade: $3 \mathrm{~km}$ de São Joaquim na estrada para Serra das Araras, 1529'S, 4510'W, elev. 600 m, J.A. Ratter et al. 8064, 5.VIII.1998, fr. (UEC).

Vochysia rufa é uma espécie de grande variação morfológica, que ocorre em cerrados de $\mathrm{BA}$, DF, GO, MA, MG, MS, MT, PA, PI, RO, SP, TO e norte da Bolívia. Está subdividida em duas subespécies, cada uma com duas variedades: $V$. rufa subsp. rufa (var. rufa e var. brevipetiolata Warm.) e V. rufa subsp. sericea [var. sericea (Pohl) Warm. e var. fulva Stafleu]. Na Serra do Cipó ocorre apenas V. rufa subsp. rufa var. rufa, que se caracteriza por ter pecíolos foliares de 2 a $3 \mathrm{~cm}$ compr.

Foi coletada com flores em março, abril e maio. Pelo material analisado, restringe-se a áreas de cerrado da porção sul da Serra do Cipó.
4.11. Vochysia schwackeana Warm., Vidensk. Meddel. Dansk Naturhist. Foren. Kjobenhavn 32: 25. 1889.

Nome vulgar: canela-santa, canela-murici.

Fig. $5 \mathrm{E}$

Árvores, $10-18 \mathrm{~m}$ alt. Ramos pruinosos, quadrangulados, casca não descamante em placas. Folhas em verticilos 4-meros; estípulas ca. $1 \mathrm{~mm}$ compr., persistentes; pecíolo 1-1,5 cm compr., tomentoso; lâmina foliar 6,5-9,3 x 2-3,2 cm, elíptica a oblongo-elíptica, cartácea; face adaxial glabra, exceto pela pubescência restrita à nervura primária, nervura primária impressa, secundárias promínulas; face abaxial glabrescente, nervuras primária e secundárias proeminentes; ápice caudado, base cuneada, margem sub-revoluta. Inflorescências terminais, laxifloras, 6-15 $\mathrm{cm}$ compr., glabrescentes; cincinos 2-4-floros, pedúnculos ca. $1 \mathrm{~cm}$ compr.; pedicelos ca. $5 \mathrm{~mm}$ compr.; brácteas caducas; botões florais 10-12 x 1 $\mathrm{mm}$, incurvos, subfalcados, ápice acuminado; cálcar 6 $8 \times 1-2 \mathrm{~mm}$, recurvo a reto, cilíndrico, ápice arredondado a globoso; sépala calcarada $1-1,5 \mathrm{~cm}$ compr.; lobos do cálice não calcarados ca. $1 \mathrm{~mm}$ compr., ovais, ápice obtuso; pétala central ca. $8 \times 5$ $\mathrm{mm}$, glabra, pétalas laterais $6 \times 4 \mathrm{~mm}$, glabras; estame ca. $1,2 \mathrm{~cm}$ compr.; antera ca. $1,15 \mathrm{~cm}$ compr., ciliada na margem; filete ca. 0,5 $\mathrm{mm}$ compr.; estaminódios ca. $1 \times 0,6 \mathrm{~mm}$; ovário ca. $1 \times 1,5 \mathrm{~mm}$, deltóide, glabro; estilete ca. $1 \mathrm{~cm}$ compr., clavado, sub-incurvo, glabro; estigma triangular, terminal. Cápsula e sementes não vistas.

Material examinado: Itambé do Mato Dentro: Distrito de Santana do Rio Preto (Cabeça de Boi), APA do Parque Nacional da Serra do Cipó, mata do Cachoeirão, 1925'55"S, 4325'58"W, M.F. Santos \& H. Serafim 239, 13.III.2008, fl. (SPF, UEC); idem, terras de José Agostinho, 1923'47"S, 4324'07"W, M.F. Santos \& H. Serafim 513, 17.III.2008, fl. (SPF, UEC).

Material adicional: São Paulo. São José dos Campos:

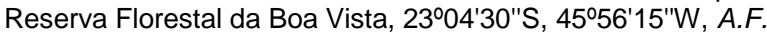
Silva \& L. Capellari Jr. 1355, 9.I.1986, fl. (UEC); idem, 2304'30"S, 4556'15"W, A.F. Silva \& L. Capellari Jr. 1366, 11.I.1986, fl. (UEC).

Vochysia schwackeana ocorre em regiões serranas no Rio de Janeiro, Minas Gerais e São Paulo. Na Serra do Cipó só há registro para matas da porção leste, no município de Itambé do Mato Dentro. $\mathrm{Na}$ área de estudo foi coletada em flor no mês de março.

Stafleu (1948) dividiu V. schwackeana em duas variedades: $V$. schwackeana Warm. var. schwackeana e V. schwackeana var. glabra Stafleu, baseando-se na redução de indumento nos ramos terminais, pecíolos e folhas da var. glabra em relação à variedade típica. Vianna (1980), considerando a variabilidade do indumento na espécie, inclusive num mesmo exemplar, sinonimizou a var. glabra com a var. schwackeana. 
Flora da Serra do Cipó, Minas Gerais: Vochysiaceae

Vochysia schwackeana diferencia-se das outras espécies do gênero com filotaxia verticilada na Serra do Cipó por apresentar ápice foliar caudado, enquanto as demais têm ápice arredondado, obtuso, emarginado ou retuso.

4.12. Vochysia thyrsoidea Pohl, PI. bras. icon. descr. 2: 24, tab. 115. 1831.

Nome vulgar: pau-de-leite, gomeira, pau-de-vinho.

Árvores ou arbustos, 1,2-8 m alt. Ramos subquadrangulados a quadrangulados, casca não descamante em placas. Folhas em verticilos 4-meros, às vezes alguns nós 6-meros; estípulas ca. $1 \mathrm{~mm}$ compr., caducas; pecíolo 1,2-2 cm compr., glabrescente; lâmina foliar (5,3-)7,5-14,5 x (2,9-)4-8,2 $\mathrm{cm}$, oblonga a oblongo-elíptica, rigidamente coriácea; face adaxial glabrescente, tomentulosa na nervura primária, nervura primária impressa, secundárias promínulas; face abaxial glabra, glabrescente quando jovem, nervura primária proeminente, secundárias promínulas a planas; ápice obtuso, retuso ou emarginado, base cuneada a obtusa, margem revoluta. Inflorescências terminais, $13-36 \mathrm{~cm}$ compr., glabrescentes; cincinos 3-7-floros, pedúnculos 1-2 cm compr.; pedicelos 7-23 mm compr.; brácteas caducas; botões florais $18-23 \times 3 \mathrm{~mm}$, retos a sub-incurvos, cilíndricos a subclavados, ápice obtuso; cálcar 8-10 x $2 \mathrm{~mm}$, reto, recurvo ou subsigmóide, cilíndrico, ápice globoso; sépala calcarada 2,8-3,5 cm compr.; lobos do cálice não calcarados ca. $2 \mathrm{~mm}$ compr., ovais, ápice agudo a arredondado; pétala central ca. $21 \times 6 \mathrm{~mm}$, glabras, pétalas laterais ca. $15 \times 4 \mathrm{~mm}$, glabras; estame ca. 2,5 cm compr.; antera ca. 2,1 cm compr., ciliada nas margens das tecas; filete ca. $4 \mathrm{~mm}$ compr.; estaminódios 1-1,5 x 0,7-1 mm; ovário ca. $2 \times 2 \mathrm{~mm}$, deltóide, glabro; estilete ca. $2,5 \mathrm{~cm}$ compr., cilíndrico, reto a incurvo, glabro; estigma trilobado, capitado, terminal. Cápsula 2,5-4 x 1,6-2,5 cm, ovóide a oblongo-ovóide, ápice agudo a arredondado, superfície verruculosa, glabra. Sementes 2,8-3,5 x 0,9$1 \mathrm{~cm}$.

Material examinado: Jaboticatubas: A.R. Barbosa s.n., 15.I.1996, fl. (UEC 81913); Rodovia Lagoa Santa Conceição do Mato Dentro - Diamantina, km 112, CFSC 3539, col. A.B. Joly \& J. Semir, 2.XI.1972, fl./fr. (SP, UEC); idem, km 115, CFSC 597, col. J. Semir \& M. Sazima, 15.XII.1971, fl. (SP); trilha principal do segundo portão depois da sede do IBAMA, subindo a Serrinha, 19-21'12"S, 4337'28"W, G.H. Shimizu \& J.G. Rando 5, 9.I.2008, fl. (UEC). Morro do Pilar: velózias gigantes, L.S. Kinoshita \& M.E. Alencar 00/401, 22.XI.2000, fl. (UEC). Santana do Riacho: G. Hatschbach \& L.F. Ferreira 35345, 25.X.1974, fl. (UEC); afloramento entre Fazenda Palácio e estátua do Juca, K. Yamamoto \& A.R. Barbosa 00/11, 22.XI.2000, fl. (UEC); Chapéu de Sol, A.P. Duarte 9073, 16.Il.1965, fl. (RB); estrada da Usina de Força, próximo ao córrego Andrequicé, $R$. MelloSilva et al. 1030, 8.IV.1995, fl./fr. (SPF); estrada para Santana do Riacho, S.M.C. Guerreiro et al. 66, 20.IX.2000, fl./fr. (UEC); Rodovia Belo Horizonte - Conceição do Mato Dentro, km 105, Vale da Mãe d'Água, CFSC 8618, col. J.D.P. Oliveira \& G.L. Esteves, 1.VIII.1982, fr. (SPF, UEC); idem, km
105, margem esquerda da Rodovia em direção à Conceição do Mato Dentro, ca. $1000 \mathrm{~m}$ da Pensão Chapéu de Sol, $A$. Salatino et al. 57, 25.IX.1995, fr. (SPF); idem, km 106, 1917'S, 4336'W, G.M. Faria \& M. Mazucato s.n., XII.1990, fl. (SPF 86622); idem, km 106, estrada para Conceição do Mato Dentro, elev. $1200 \mathrm{~m}$, G. Martinelli et al. 11329, 25.I.1986, fl./fr. (RB, SPF); idem, km 107, caminho para Usina Dr. Pacífico Mascarenhas, CFSC 9033, col. E. Forero et al., 7.IX.1980, fr. (SP, SPF); idem, km 109, próximo à estrada da Usina Dr. Pacífico Mascarenhas, CFSC 12347, col. J.R. Pirani et al., 31.V.1991, fr. (SPF); idem, km 114, CFSC 8578, col. J.D. Pinheiro \& G.L. Esteves, 31.VII.1982, fr. (SPF); idem, km 131 e 132, Palácio, A.P. Duarte 2045, 4.XII.1949, fl. (RB); Parque Nacional da Serra do Cipó, elev. 1100 m, M. Pereira et al. 797, 23.XI.1991, fl. (GUA). Sem localidade: estrada Lagoa Santa - Conceição do Mato Dentro, km 98 (antigo 114), M.S.F. Silvestre s.n., 2.XI.1978, fl./fr. (UEC 15860); Serra do Cipó, A.B. Martins s.n., 1978, fl. (UEC 62845).

Vochysia thyrsoidea ocorre na BA, CE, DF, GO, MG e SP, em áreas de cerrado e campo rupestre. É uma espécie amplamente distribuída na Cadeia do Espinhaço e em outras áreas, como a Serra da Canastra e a Chapada dos Veadeiros. Na Serra do Cipó foi coletada em flor em janeiro, fevereiro, abril e de setembro a dezembro, e em fruto nos meses de janeiro, fevereiro, abril, maio, julho a setembro e novembro. É uma das espécies de Vochysiaceae mais frequentes na área de estudo.

Apesar de ser muito semelhante morfologicamente a $V$. tucanorum, diferencia-se principalmente pelo tamanho e textura das estruturas, sempre maiores e mais crassas. Vochysia thyrsoidea apresenta folhas coriáceas com a margem revoluta, ao passo que $V$. tucanorum apresenta folhas cartáceas com a margem sub-revoluta, revoluta apenas na porção basal. Nos materiais analisados da Serra do Cipó, as folhas em $V$. thyrsoidea são geralmente mais largas, ca. 4-8 cm, enquanto em $V$. tucanorum atingem até ca. $3 \mathrm{~cm}$ de largura. Em $V$. thyrsoidea o ápice do cálcar é globoso, as cápsulas são maiores (2,5-4 $\mathrm{x}$ 1,6-2,5 cm) e ovóides a oblongo-ovóides, ao passo que em $V$. tucanorum o ápice do cálcar é arredondado, as cápsulas variam de 1,8-2,1 x 1-1,2 $\mathrm{cm}$ e são oblongas a oblongo-elípticas. Também é muito semelhante à Vochysia microphylla, em relação ao formato das folhas, flores e frutos. Difere por não apresentar hábito cespitoso e por ter estruturas maiores, principalmente as folhas, que geralmente ultrapassam $7 \mathrm{~cm}$ de comprimento. Espécie ilustrada em Pohl (1831, fig. 115) e Barbosa (1999, fig. 35).

4.13. Vochysia tucanorum Mart., Nov. Gen. sp. pl. 1: 142, tab. 85. 1826.

Nome vulgar: caixeta, congonha, pau-de-tucano, vinhático-do-campo.

Árvores ou arbustos 1,5-8 m alt. Ramos subquadrangulados a quadrangulados, casca não descamante em placas. Folhas em verticilos 4-meros; estípulas ca. $1 \mathrm{~mm}$ compr., tardiamente caducas; pecíolo 0,4-1 cm compr., glabro; lâmina foliar 3-7,5 x 
1,5-3 cm, oboval, oboval-oblonga, elíptica, cartácea; face adaxial glabra a esparsamente pubescente sobre a nervura primária e base foliar, nervura primária impressa, secundárias proeminentes; face abaxial glabra, nervura primária proeminente, laterais promínulas; ápice obtuso, retuso ou emarginado, base cuneada, margem sub-revoluta, revoluta na base foliar. Inflorescências terminais, 9-18 cm compr., glabrescentes; cincinos 3-5-floros, pedúnculos 2-5 mm compr.; pedicelos 3-8 mm compr.; brácteas caducas; botões florais $12-20 \times 2 \mathrm{~mm}$, incurvos, cilíndricos, ápice agudo a arredondado; cálcar 6-12 x $1 \mathrm{~mm}$, recurvo, às vezes sigmóide ou reto, cilíndrico, ápice arredondado; sépala calcarada 1-1,9 cm compr.; lobos do cálice não calcarados 2-3 mm compr., ovais, ápice obtuso a arredondado; pétala central ca. $15 \times 3 \mathrm{~mm}$, glabra ou ciliada no ápice, pétalas laterais 8-10 x 2-3 $\mathrm{mm}$, glabras ou ciliadas no ápice; estame 1,3-1,5 cm compr.; antera 1-1,1 cm compr., ciliada nas margens das tecas; filete 2-5 mm compr.; estaminódios 1-1,5 $\mathrm{x}$ 0,7-1 mm; ovário 1-2 x 1-2 mm, deltóide, glabro; estilete 1,8-2 cm compr., subclavado, reto a subincurvo, glabro; estigma subtriangular a triangular, subterminal. Cápsula 1,8-2,1 x 1-1,2 cm, oblonga a oblongo-elíptica, ápice obtuso, arredondado ou retuso, superfície verruculosa, glabra. Sementes ca. $17 \times 5$ $\mathrm{mm}$.

Material examinado selecionado: Jaboticatubas: $A . R$. Barbosa s.n., 15.I.1996, fl. (UEC 81907); Rodovia Lagoa Santa - Conceição do Mato Dentro - Diamantina, km 126 , CFSC 4437, col. J. Semir et al., 5.IX.1973, fr. (UEC). Santana de Pirapama: Fazenda Inhame, 185'S, 4354'W, CFSC 8157, col. I. Cordeiro et al., 23.III.1982, fl. (SPF, UEC). Santana do Riacho: 1920'S, 4336'W, elev. $800 \mathrm{~m}, O . A$ Salgado 252, 28.XI.1981, fl. (RB); $500 \mathrm{~m}$ antes do Juquinha, lado direito no morro, na mata, S.M.C. Guerreiro et al. 19, 19.IX.2000, fr. (UEC); córrego atrás do morro ao lado direito da estátua do Juquinha, L.M. Borges et al. 31, 20.II.2005, fl. (SPF); córrego Duas Pontinhas, 1917'30"S, 43ำ34'06"W, elev. 1165-1272 m, F. França et al. 2598, 5.VII.1998, fr. (SPF); estrada da Usina de Força, próximo ao córrego Andrequicé, R. Mello-Silva et al. 1029, 8.IV.1995, fr. (SP, SPF); estrada de São José de Almeida a Conceição do Mato Dentro, elev. 1250 m, C.E.B. Pereira 346, 26.Xl.1998, fl. (GUA); estrada Lagoa Santa - Conceição do Mato Dentro, vegetação de cerrado próxima ao Hotel Chapéu de Sol, $T$. Wendt \& F.A. Vitta 114, 3.II.1987, fl. (RB); estrada MG-010 Conceição do Mato Dentro, ca. $400 \mathrm{~m}$ antes da bifurcação entre o Morro do Pilar e Conceição do Mato Dentro, capão de mata grande a $W$ da rodovia, CFSC 13325 , col. M.T.V.A. Campos \& N. Roque, 8.VIII.1993, fl./fr. (SP, SPF); idem, CFSC 13587, col. M.T.V.A. Campos \& J.M. Arcanjo, 18.XII.1993, fl. (SPF); Fazenda Alto Palácio, 1917'S, 4334'W, elev. 1140 m, E.F. Almeida 168, 23.IX.1981, fr. (GUA); km 112, córrego Duas Pontinhas, elev. $1250 \mathrm{~m}$, CFSC 13872, col. M. Sztutman et al., 5.IV.1995, fl./fr. (SPF); Rodovia Lagoa Santa - Conceição do Mato Dentro Diamantina, km 116, mata ciliar do córrego Indequicé, CFSC 7226, col. A. Furlan et al., 19.IV.1981, fl./fr. (SPF, UEC); idem, km 116, córrego Duas Pontinhas, CFSC 11438, col. J.R. Pirani \& M.C.P. Bonfim, 20.V.1989, fr. (SPF); idem, km 128, CFSC 9761, col. R. Mello-Silva et al., 3.V.1986, fl./fr. (SPF); idem, km 128, borda do capão virado para o declive da estrada, CFSC 11066, col. A.E. Luchi et al., 7.IV.1987, fl. (SP, SPF); idem, km 132, elev. 1150 m, A.P. Duarte 2152,
6.XII.1949, fl. (RB); idem, km 133, A.P. Duarte 9629, 23.III.1966, fl./fr. (RB); Pico do Breu, M. Pereira et al. 798, 15.VII.1991, fr. (GUA); próximo ao Córrego Três Pontinhas, a $7,5 \mathrm{~km}$ da Pensão Chapéu de Sol, G.H. Shimizu \& J.G. Rando 16, 10.I.2008, fl. (UEC); Rodovia Belo Horizonte Conceição do Mato Dentro, APA Morro da Pedreira, mata ciliar do córrego Duas Pontinhas, 1917'27"S, 4334'05"W, elev. 1200 m, J.R. Pirani et al. 5007, 5.III.2002, fl. (SPF, UEC).

Vochysia tucanorum é uma das espécies mais amplamente distribuídas de Vochysiaceae, ocorrendo em BA, DF, ES, GO, MG, MS, MT, PR, RJ, SP e TO, leste da Bolívia e Paraguai, em bordas de mata, capões de mata, matas de galeria, cerradões, geralmente associada a rios ou lagos. É bastante frequente e geralmente abundante em toda a Serra do Cipó. Foi coletada em flor de janeiro a maio, agosto e dezembro, e em fruto em abril, maio e de julho a setembro.

Barbosa (1999), examinando vasta amostragem da grande variabilidade morfológica de $V$. tucanorum, fotos de tipos e descrições, propôs a sinonimização (ainda inédita) de $V$. tucanorum var. fastigiata Mart. sob V. tucanorum. Segundo a autora, $V$. tucanorum apresenta estruturas vegetativas $\mathrm{e}$ reprodutivas com dimensões geralmente menores em regiões serranas, e dimensões maiores em cerrados e cerradões em regiões não serranas, mas sem haver descontinuidade entre essas duas formas. As diferenças entre $V$. tucanorum e $V$. thyrsoidea, espécie com a qual a primeira mais se assemelha na Serra do Cipó, são apresentadas nos comentários de $V$. thyrsoidea. Espécie ilustrada em Barbosa (1999, fig. 36).

\section{Agradecimentos}

Os autores agradecem à CAPES pela bolsa de mestrado concedida ao primeiro autor, ao Programa de Pós-Graduação em Biologia Vegetal da Unicamp, aos curadores dos herbários que disponibilizaram suas coleções e a Rafael Arruda pelas ilustrações.

\section{Referências}

BARBOSA, A.R. 1999. As espécies do gênero Vochysia Aubl. (Vochysiaceae) ocorrentes no Estado de São Paulo. Dissertação de Mestrado. Universidade Estadual de Campinas. Campinas.

FRANÇA, F. 1996. O gênero Callisthene Mart. \& Zucc. (Vochysiaceae) no estado da Bahia. Sitientibus 15: 4147.

FRANCA, F. 2005. Vochysiaceae. In T.B. Cavalcanti \& A.E. Ramos (eds.) Flora do Distrito Federal, Brasil. Vol. 4. Embrapa Recursos Genéticos e Biotecnologia. Brasília, p. $79-106$. 
Flora da Serra do Cipó, Minas Gerais: Vochysiaceae

GIULIETTI, A.M., MENEZES, N.L., PIRANI, J.R., MEGURO, M. \& WANDERLEY, M.G.L. 1987. Flora da Serra do Cipó, Minas Gerais: caracterização e lista das espécies. Bol. Bot. Univ. São Paulo 9: 1-151.

KAWASAKI, M.L. 1995. Vochysiaceae. In B.L. Stannard (ed.) Flora of the Pico das Almas - Chapada Diamantina, Bahia, Brazil. Royal Botanic Gardens. Kew, p. 639-643.

KAWASAKI, M.L. 2006. Vochysiaceae. In K. Kubitzki (ed.) The families and genera of vascular plants. Springer. Berlin, vol. 9, p. 480-487.

LISBOA, M.L.G. 2000. Estudos taxonômicos sobre o subgênero Amphilochia (Mart.) Stafl., gênero Qualea Aubl. (Vochysiaceae A. St.-Hil.). Dissertação de Mestrado. Universidade Estadual de Campinas. Campinas.

MARTINS, H.F. 1981. O gênero Callisthene Martius (Vochysiaceae). Ensaio para uma revisão taxonômica. Dissertação de Mestrado. Universidade Federal do Rio de Janeiro. Rio de Janeiro.

MARTINS, H.F. 1988. Species novae in Brasilia Vochysiacearum. Bradea 5 (13): 149-151.

MARTIUS, C.F.P. 1826. Nova genera et species plantarum. Lindauer. München, vol. 1.

PASSOS, V.M. \& FRANÇA, F. 2003. Vochysiaceae da Chapada Diamantina, Bahia, Brasil. Sitientibus Sér. Ci. Biol. 3 (1/2): 35-43.

POHL, J.B.E. 1831. Plantarum Brasiliae icones et descriptiones hactenus ineditae. Antonii Strauss. Vienna, vol. 2.

SHIMIZU, G.H. 2009. Vochysiaceae na Serra do Cipó, Minas Gerais, Brasil. Dissertação de Mestrado. Universidade Estadual de Campinas. Campinas.

SHIMIZU, G.H. \& YAMAMOTO, K. 2012. Vochysiaceae. In C.M. Jacobi \& F.F. Carmo (orgs.) Diversidade florística nas cangas do Quadrilátero Ferrífero. Código Editora. Belo Horizonte, p. 209-210.
SILVA, M.F.F., SECCO, R.S. \& LOBO, M.G.A. 1996. Aspectos ecológicos da vegetação rupestre da Serra dos Carajás, Estado do Pará, Brasil. Acta Amazonica $26(1 / 2): 17-44$.

STAFLEU, F.A. 1948. A monograph of Vochysiaceae. I. Salvertia and Vochysia. Recueil Trav. Bot. Néerl. 41: 397-540.

STAFLEU, F.A. 1952. A monograph of Vochysiaceae. II. Callisthene. Acta Bot. Neerl. 1: 222-242.

STAFLEU, F.A. 1953. A monograph of Vochysiaceae. III. Qualea. Acta Bot. Neerl. 2: 144-217.

STAFLEU, F.A. 1954. Novitates vochysiacearum I. Acta Bot. Neerl. 3 (3): 405-411.

STAFLEU, F.A. \& COWAN, R.S. 1981. Taxonomic Literature. A selective guide to botanical publications and collections with dates, commentaries and types. Regnum Veg. 105: 1-980. Bohn, Scheltema \& Holkema; Junk. Utrecht; The Hague, ed. 2, vol. 3 (Lh-O).

STAFLEU, F.A. \& COWAN, R.S. 1985. Taxonomic Literature. A selective guide to botanical publications and collections with dates, commentaries and types. Regnum Veg. 112: 1-1066. Bohn, Scheltema \& Holkema; Junk. Utrecht/Antwerpen; The Hague/Boston, ed. 2, vol. 5 (Sal-Ste).

VIANNA, M.C. 1980. O gênero Vochysia Aublet (Vochysiaceae) no Estado do Rio de Janeiro. Rodriguésia 55: 237-323.

VIANNA, M.C. 2002. Vochysia Aubl. (Vochysiaceae) na Mata Atlântica: Morfologia e Taxonomia. Tese de Doutorado. Universidade Federal do Rio de Janeiro. Rio de Janeiro.

WARMING, E. 1875. Vochysiaceae. In C.F.P. Martius \& A.W. Eichler (eds.) Flora brasiliensis. Frid. Fleischer. Leipzig, vol. 13, pars 2, p. 17-116, tabs. 2-21.

YAMAMOTO, K. 2009. Flora de Grão-Mogol, Minas Gerais: Vochysiaceae. Bol. Bot. Univ. São Paulo 27: 131-136. 